\title{
LIBERTAD DE CULTO E INSTITUCIONES PÚBLICAS
}

\author{
JOSÉ LUIS LECAROS CORNEJO*
}

\begin{abstract}
Resumen
Se analiza el modelo de relación Estado-Iglesia sobre la base del principio de laicidad, a fin de determinar el contenido y los alcances del derecho de libertad religiosa, en lo relativo a la libertad de culto al interior de las instituciones públicas.
\end{abstract}

Palabras clave: Estado, religión, laicidad, libertad religiosa, libertad de conciencia, libertad de culto, jurisprudencia, instituciones públicas.

\begin{abstract}
We analyze the model of the relationship Church- State, on the base of the principle of secularism, in order to determine the content and the rights of religious freedom, related with the freedom of worship within the public institutions.
\end{abstract}

Keywords: . State, religion, secularism, religious freedom, freedom of conscience, freedom of worship, jurisprudence.

\section{Sumario}

1.- Introducción. 2.- El principio de laicidad. 2.1.- Concepto, características; 2.2.- El Estado laico. 3. Estado-Iglesias y principio antidiscriminatorio. 4 . El derecho de libertad religiosa. 4.1.- Estado de la cuestión en España; 4.2 Jurisprudencia del Tribunal Constitucional español y del Tribunal de Estrasburgo. 4.2.1.- Jurisprudencia del Tribunal Constitucional español. 4.2.2.- Jurisprudencia del Tribunal Europeo de Derechos Humanos. 4.2.3.- Sobre el criterio del «margen de apreciación». 4.3.- En el constitucionalismo latinoamericano. 4.4.- Estado de la cuestión en el Perú. 4.4.1.Antecedentes sobre la cuestión religiosa. 4.4.2.- Recepción del derecho fundamental a la libertad religiosa en el Perú. 4.4.3.- La Ley No 29635, ley de libertad religiosa y su reglamento. 4.4.4.Jurisprudencia del Tribunal Constitucional. 5.- Libertad de culto en las instituciones públicas. 5.1.- Libertad de culto. 5.2.- Libertad de culto e instituciones públicas. 5.2.1.- Culto religioso en los actos oficiales del Estado. 6.- Conclusiones.

* Juez titular de la Corte Suprema de Justicia de la República del Perú y miembro del Consejo Ejecutivo del Poder Judicial peruano. 


\section{Introducción}

El análisis del vínculo entre el Estado y la religión implica acercarse a cómo se articulan los roles que cumplen dentro de la sociedad de acuerdo a sus particulares enfoques y fines. Dicho objeto de estudio no es ajeno al derecho, al punto que se ha afirmado que la forma de organizar las relaciones que deben existir entre ambas instituciones es uno de los aspectos más importantes del derecho Constitucional y la base fundamental de una buena organización social ${ }^{1}$.

Dada la importancia de la cuestión religiosa, el Estado no puede permanecer indiferente; de ahí que resulte lógico comprender el hecho de que cada Estado adopte una posición particular frente al fenómeno religioso, situación que da lugar a múltiples modelos de la relación Estado-Iglesia, entre los cuales destacan el modelo de unión, el modelo de separación, el modelo de coordinación y el modelo de hostilidad o persecutorio ${ }^{2}$. Ello es en efecto importante porque el derecho a la libertad religiosa está necesariamente conectado con el sistema o modelo de relaciones Iglesias - Estado que rige en cada país 3 .

\section{El principio de laicidad}

\subsection{Concepto, características}

Laico, según el Diccionario de la lengua española, deriva de la palabra latina lă̌cus, adjetivo que se aplica a quien es independiente de cualquier organización o confesión religiosa. Asimismo, el laicismo no es una doctrina confrontada con otras, es una posición frente a la pluralidad de doctrinas, particularmente religiosas, que reclaman por igual la validez de su visión del mundo. Ser laico significa reconocer el derecho de todos a practicar una religión -si esa es su decisión- y hacerlo en el ámbito de la familia, de las propias comunidades religiosas y de las organizaciones ligadas a ellas ${ }^{4}$.

Asimismo, la laicidad refiere a la separación entre el Estado y la Iglesia, y como tal es entendida como un régimen social de la convivencia cuyas instituciones políticas están legitimadas principalmente por la soberanía popular y ya no por elementos

1 PAREjA PAZSOLDÁN, José. Derecho Constitucional peruano y la Constitución de 1979. Justo Valenzuela V. Lima, 1980, p. 493.

2 DE DENHEIM BARRIGUETE, Cuauhtémoc Manuel. “El derecho a la libertad religiosa y la laicidad del Estado como presupuestos básicos del Estado Constitucional y Social de Derecho", en Vizcaíno López, María Teresa (coord.): Estado laico, democracia y derechos fundamentales. Facultad de Derecho y Ciencias Sociales UMSNH, México, 2010, p. 31.

3 Olmos OrtegA, María Elena. El derecho a la libertad religiosa: un tema de nuestro tiempo, p. 2, en http://www.ligaproderechoshumanos.org/articulos/maria-elena-olmos-ortega.pdf (consultada el 2801-2016).

4 FUENTES MOLINAR, Olac. "El laicismo: seis tesis contrarias a la educación pública”, en Bases Filosóficas, Legales y Organizativas del Sistema Educativo Mexicano. Secretaría de Educación Pública, México, 1997, p. 41. 
religiosos $^{5}$. La laicidad no afecta negativamente en ningún caso a la libertad de expresión o manifestación, individual o colectiva, de las convicciones y creencias, religiosas o no. Al contrario, la laicidad es la única garantía eficaz del pluralismo, valor superior del ordenamiento y resultado del ejercicio de la libertad de expresión de las creencias, ideas u opiniones ${ }^{6}$.

A fin de esclarecer los aspectos jurídicos del principio de laicidad, en doctrina se propone una concepción técnica jurídica: la laicidad es un principio constitucional que establece la separación entre el Estado y la Iglesia o las Iglesias que hasta ese momento hubieran servido como referentes normativos, así como el conjunto de mecanismos jurídico-institucionales que garantizan y desarrollan este principio. De ese modo, el concepto de laicidad, no sirve para construir modelos abstractos de laicidad, sino para describir marcos jurídico-institucionales que prevén mecanismos que, más o menos eficazmente, permiten actuar y garantizar la idea de separación entre Estado y religiones ${ }^{7}$.

A decir de Carretero 8 , el laicismo es un ideario ético-político que persigue la autonomía de la sociedad con respecto de cualquier legitimación del mundo de carácter extrasocial. El laicismo buscará afianzar el ideal de un modelo de sociedad plenamente autoinstituida, liberada de toda instancia instituyente ajena a lo social. El fin último es conseguir una sociedad donde el individuo pueda desarrollar su libertad sin ningún tipo de coacción o imperativo externo.

Se trata de un principio constitucional que reconoce valores democráticos que dentro de un determinado marco jurídico-político se encuentran desligados de los preceptos religiosos a fin de proteger la libertad de conciencia individual y, como consecuencia, proteger la libertad religiosa misma. El principio de laicidad se sobrepone -por tantoa la confesionalidad estatal heredada de la histórica relación entre Estado-Iglesia.

5 BOKSER LIWERANT, Judit. “Religión y espacio público en los tiempos de la globalización", en R. Blancarte (coord.): Los retos de la laicidad y la secularización en el mundo contemporáneo. El Colegio de México. Centro de Estudios Sociológicos, 2008, México D.F., p. 63.

6 Llamazares Fernández, Dionisio. Libertad de conciencia y laicidad en las instituciones y servicios públicos. Madrid, Editorial Dykinson, 2005, p. 14.

7 MORONDOTARAMUNDI, Dolores. El principio de laicidad y el principio antidiscriminatorio en la discusión sobre la libertad religiosa. Diritto e questioni pubbliche, n. 13/2013, Palermo, 2013, p. 597, en http://www.dirittoequestionipubbliche.org/page/2013_n13/stu_08-Morondo.pdf (consultada el 11-0116).

8 CARRETEROPASín, ANGel Enrique. El laicismo. ¿Una religión metamorfoseada?, Nómadas. Revista Crítica de $\begin{array}{lllll}\text { Ciencias Sociales } & y & \text { Jurídicas, } & \text { (2007.1), }\end{array}$ http://revistas.ucm.es/index.php/NOMA/article/view/NOMA0707120239A/26558 (consultada el 1612-2015). 


\subsection{El Estado laico}

En función al principio de laicidad, según Santana ${ }^{9}$, se define al Estado laico como aquel que se encuentra fuera de toda influencia religiosa o de enseñanza religiosa. En este sentido, el Estado laico no se adhiere a ninguna religión, ni declara a una religión determinada como la oficial del Estado. Como refiere Pardo ${ }^{10}$, el Estado laico es un Estado para la libertad. Un Estado cuya existencia solo tiene sentido a través de la garantía de la libertad de conciencia personal, siempre que esta se halle dispuesta al consenso y al respeto de los valores democráticos. El Estado laico no limita ni dificulta el desarrollo de las cosmovisiones dispuestas al consenso en torno a los valores comunes, no resta valor a algunas de estas para favorecer a otras. $\mathrm{Su}$ objetivo primordial es proporcionar los medios para que cada ciudadano pueda estar en condiciones de llevar a cabo su programa de realización individual, sin más inconvenientes y sin menos ayudas que el resto.

No obstante, definir exactamente la actitud que el Estado asume frente al factor religioso es un problema complejo; problema que es común a todos los países occidentales en los que al parecer rige el principio de laicidad, porque aun cuando constitucionalmente se encuentre adoptado como valor superior del ordenamiento jurídico del Estado, dicho principio no es inmutable sino variable en función de los movimientos sociales, culturales y políticos, del momento ${ }^{11}$. De ahí que la eficacia de los mecanismos de garantía de la separación se evaluaría en relación a principios y valores que vienen a justificar la necesidad de la separación (generalmente, aunque no solo, la libertad de conciencia y religión y la igualdad). Sin embargo, dicho análisis debe tener en cuenta también el marco concreto de laicidad y las dinámicas que pueden condicionar el funcionamiento de los mecanismos de separación ${ }^{12}$.

\section{Estado-Iglesias y principio antidiscriminatorio}

Siguiendo a Morondo ${ }^{13}$, el enfoque Estado-Iglesias resulta problemático desde el punto de vista del principio antidiscriminatorio en relación a la libertad religiosa a causa de la "privatización" de la religión. Originariamente la libertad religiosa protegía a los individuos en cuanto miembros de una determinada confesión

\footnotetext{
9 SANTANA, Alejandro. El Estado laico y la reforma constitucional. Consulta Anual 2009 Núcleo FTL República Dominicana - Iglesia, Poder y Misión en la República Dominicana Hoy, 2009, en https:/ ftldominicana.files.wordpress.com/2010/01/el-estado-laico-y-la-reforma-constitucional-e28094alejandro-santana.pdf (consultada el 17-12-15).

10 PARDO PRIETO, Paulino C. "Secularización y Sistema Concordatorio Histórico Español de 1753 y 1851", en A. Pele, O. Celador Angón y H. Garrido Suárez (AAVV). La laicidad. Madrid, Editorial Dykinson, 2014, p. 26.

11 ARECESPIÑOL, Ma Teresa. El principio de laicidad en las jurisprudencias española y francesa. Lleida, Ediciones de la Universidad de Lleida, España, 2003, p. 32.

12 MORONDOTARAMUNDI, Dolores. Op. cit, p. 597.

13 MORONDOTARAMUNDI, Dolores. Op. cit., p. 599.
} 
religiosa, pero hoy se entiende de forma radicalmente diversa, en primer lugar porque tiene carácter subjetivo e individual, pero además porque se entiende como una "cuestión privada". Esto es, principalmente, el resultado de la "libertad negativa" en materia de libertad religiosa. La "libertad negativa" significa, en el ámbito del artículo 9.1 del Convenio Europeo de Derechos Humanos, dos cosas diversas: a) En primer lugar, significa que el artículo 9.1 protege también a quien tenga creencias areligiosas o anti-religiosas (ateos, agnósticos, indiferentes, etc.). b) En un segundo sentido, la "libertad negativa" significa no estar sujeto a las prácticas religiosas de un grupo determinado, la libertad de no creer, de no ser adoctrinado $\mathrm{u}$ obligado a las prácticas religiosas de otros. Este segundo sentido de la "libertad negativa" (libertad respecto de la religión) afecta a los no creyentes, pero atañe también a los creyentes de una religión respecto de las otras religiones, a los disidentes religiosos en relación a la ortodoxia de su propia religión y, en general, a cualquier creyente en relación a la propia religión, que se configura así como una "cuestión privada", un acto voluntario cuyas prácticas, ritos y manifestaciones no pueden ser exigidos a los individuos a través del Estado. La religión se privatiza, pues, en el ámbito de la voluntad individual.

En tal contexto, con la religión entendida como convicción personal y privada, las distinciones que provoca el marco institucional basado en un mayor reconocimiento público, mayor protección y mayores posibilidades de acción a las prácticas (religiosas y religioso-culturales, puesto que el Estado no puede entrar a valorar la ortodoxia de las prácticas) de los que puedan identificarse con una de las religiones con las que el Estado tiene determinados acuerdos, comprometen el principio antidiscriminatorio en relación a las minorías religiosas, a las formas de creencia que no pueden (o difícilmente pueden) estructurarse según el modelo de las religiones tradicionales, a la disidencia religiosa y a los no creyentes.

Compromete además el principio antidiscriminatorio de otra manera, esta perspectiva constituye la función típica y tradicional de las normas antidiscriminatorias: proteger a ciertos grupos "vulnerables" o "minoritarios" de comportamientos desfavorables contra sus miembros. Sin embargo, el principio antidiscriminatorio tiene también la capacidad de cuestionar la acumulación de privilegio por parte de la mayoría o de los grupos dominantes, que es la otra cara de la desigualdad. Es decir, el principio antidiscriminatorio y el derecho antidiscriminatorio tienen la capacidad de cuestionar las estructuras de subordinación de los grupos que definen las relaciones de poder sobre las que se asientan los comportamientos discriminatorios. El análisis antidiscriminatorio debe llevarnos también a examinar las estructuras de subordinación. Dichas estructuras responden y constituyen relaciones de poder entre grupos oprimidos o subordinados y grupos dominantes. El enfoque de la laicidad como relación EstadoIglesia(s)/confesiones, como remarca Morondo, dificulta esta capacidad del principio antidiscriminatorio para denunciar las estructuras de subordinación porque actúa 
como mecanismo de legitimación de la hegemonía de ciertas posiciones, presentando el privilegio como simple alteridad.

\section{4. $\quad$ El derecho de libertad religiosa}

La libertad religiosa debe ser entendida como un derecho fundamental, tanto desde una perspectiva procesal -susceptible de tutela por medio de los recursos de amparo en los ordenamientos donde así se ha establecido-, como desde una óptica material en tanto se trata de un derecho fundamental que ha sido reconocido a cualquier ser humano por esa condición, inherente a la dignidad de cada uno de ellos ${ }^{14}$. No obstante, deben considerarse los límites a la libertad de religión, en la medida en que no se trata de un derecho de contenido absoluto, sino que puede ser razonablemente restringido para tutelar los derechos de terceros y el orden público, así como sus garantías jurisdiccionales; de forma que el juicio de ponderación constituye una herramienta indispensable para asegurar su aplicación frente a otros derechos y libertades fundamentales ${ }^{15}$.

Pero en cuanto a la libertad religiosa en sí, no hay propiamente una definición unánime. Los textos internacionales de protección de derechos humanos no la individualizan sino que la incluyen en la tríada de la libertad de pensamiento, de conciencia y de religión; instrumentos los cuales afirman que la religión configura y marca la vida de las personas, pues constituye uno de los elementos fundamentales de la concepción de la vida ${ }^{16}$. Puede precisarse, sin embargo, que la Declaración conciliar "Dignitatis Humanae", sobre la libertad religiosa, ofrece en su numeral 2 una noción general diciendo que esta libertad "consiste en que todos los hombres han de estar inmunes de coacción, tanto por parte de personas particulares como de grupos sociales y de cualquier potestad humana, y esto de tal manera, que en materia religiosa ni se obligue a nadie a obrar contra su conciencia ni se le impida que actúe conforme a ella en privado y en público, solo $o$ asociado con otros, dentro de los límites debidos". De acuerdo a lo anteriormente expresado, se puede decir que "la libertad religiosa es la facultad o el derecho que tiene toda persona, sola o asociada, de vivir conforme o en desacuerdo con sus propias creencias o convicciones religiosas" ${ }^{\prime 17}$.

De otro lado, la libertad de religión comprende tanto las acciones realizadas a partir de una valoración inicial positiva del fenómeno religioso, como las negativas: agnósticas o ateas ${ }^{18}$; y, por consiguiente, en cualquiera de ambos supuestos, es la

14 OROZCO SOlANO, Víctor Eduardo. Laicidad y Libertad de Religión. Maestría en Justicia Constitucional, Universidad de Costa Rica, 2010, p. 23, en http://sitios.poderjudicial.go.cr/salaconstitucional/articulos\%20y\%20conferencias/Laicidad\%20y\%20Libertad\%20de\%20R eligion.pdf (consultada el 08-01-16)

15 OROZCOSOLANO, Víctor Eduardo. Op. cit., p.24.

16 OlmosOrTEGA, María Elena. Op. cit, p. 8.

17 Ibídem.

18 OrOZCOSOlANO, Víctor Eduardo. Op. cit., p. 45. 
elección del particular la que viene a ser protegida como derecho fundamental a la libertad religiosa. Adicionalmente al concepto tradicional de confesión o religión, han de tenerse en cuenta las nuevas formas de religión, diversos desarrollos de la filosofía de la religión que proyectan los sentimientos religiosos hacia otros objetos que no necesariamente tienen que ver con Dios ${ }^{19}$.

\subsection{Estado de la cuestión en España}

En España, la transformación del Concordato de 1953, en los Acuerdos de 1979 con la Santa Sede, debatidos en un contexto en el que todavía no se había cerrado el texto constitucional, dejó abierta una sospecha sobre la "benevolencia" del Estado para con la Iglesia Católica a la hora de mantener una serie de privilegios muy especialmente en materias "sensibles" como la educación y el sostenimiento económico de la Iglesia $^{20}$. En efecto, si bien la Constitución española garantiza la libertad ideológica, religiosa y de culto de los individuos y las comunidades -aunque se señala que, ninguna confesión religiosa tendrá carácter estatal-, la Iglesia católica se beneficia de una posición privilegiada. Así se señala en el art. $16.3^{\circ}$ de la Constitución: "Los poderes públicos mantendrán relaciones de cooperación con la Iglesia católica y las demás confesiones religiosas". Asimismo, la Constitución garantiza el derecho que ostentan los padres de elegir la enseñanza religiosa para sus hijos, tanto en los centros educativos públicos como privados ${ }^{21}$.

Puede decirse, no obstante, que la Constitución de España, al garantizar la libertad ideológica, religiosa y de culto, impone como doble exigencia la neutralidad de los poderes públicos -es decir como un Estado aconfesional- y el mantenimiento de relaciones de cooperación de los poderes públicos con las iglesias; todo ello sin más limitación en sus manifestaciones, de acuerdo al art. 16.1, que la necesaria para el mantenimiento del orden público protegido por la ley. A su vez, la Ley Orgánica 7/1980, de Libertad Religiosa, de 5 de julio, establece en el artículo primero que: Uno. El Estado garantiza el derecho fundamental a la libertad religiosa y de culto, reconocida en la Constitución. Dos. Las creencias religiosas no constituirán motivo de desigualdad o discriminación ante la Ley. No podrán alegarse motivos religiosos para impedir a nadie el ejercicio de cualquier trabajo o actividad o el desempeño de cargos o funciones públicas; y, Tres. Ninguna confesión tendrá carácter estatal.

19 Caso contrario, quedaría fuera del concepto de religión o confesión el Budismo, por ejemplificar un caso.

20 URRUTIA ABAIGAR, Víctor. “Laicismo y laicidad”. FRONTERA, número 35, julio-septiembre 2005: Laicidad, laicismo y fe cristiana, en http://2001.atrio.org/PRIVADO/FRONTERA/35/35-VIctor.pdf (consultada el 18-12-15).

21 LABACA ZABALA, María Lourdes. La libertad religiosa y el principio de laicidad en los centros educativos de Francia: a propósito de las manifestaciones religiosas ostensibles en las aulas, 2007, p. 478, en http://www2.congreso.gob.pe/sicr/cendocbib/con4_uibd.nsf/A3948EB41827E67205257C7100745458/ \$FILE/24-la-libertad-religiosa-y-principio-laicidad.pdf (consultada el 11-01-16). 


\subsection{Jurisprudencia del Tribunal Constitucional español y del Tribunal de Estrasburgo}

\subsubsection{Jurisprudencia del Tribunal Constitucional español}

El Tribunal Constitucional español ha analizado en diversas sentencias el tema de las manifestaciones religiosas en las instituciones públicas, así como los principios de laicidad y libertad religiosa. Ya en la STC 24/1982, de 13 de mayo, parte con claridad indicando que el artículo 16.3 de la Constitución proclama que "ninguna confesión tendrá carácter estatal" e impide que los valores o intereses religiosos se erijan en parámetros para medir la legitimidad o justicia de las normas y actos de los poderes públicos; vedando cualquier tipo de confusión entre funciones religiosas y funciones estatales (fundamento 1). Agrega el Tribunal que, en virtud del principio de libertad religiosa, "el Estado se prohíbe a sí mismo cualquier concurrencia, junto a los ciudadanos, en calidad de sujeto de actos o de actitudes de signo religioso".

En la sentencia 177/1996, de 11 de noviembre, referido a la participación en ceremonias oficiales de contenido religioso en las instituciones estatales, razona en el fundamento 10 de su resolución: "el art. 16.3 C.E. no impide a las Fuerzas Armadas la celebración de festividades religiosas o la participación en ceremonias de esa naturaleza. Pero el derecho de libertad religiosa, en su vertiente negativa, garantiza la libertad de cada persona para decidir en conciencia si desea o no tomar parte en actos de esa naturaleza. Decisión personal, a la que no se pueden oponer las Fuerzas Armadas que, como los demás poderes públicos, sí están, en tales casos, vinculadas negativamente por el mandato de neutralidad en materia religiosa del art. 16.3 C.E. En consecuencia, aun cuando se considere que la participación del actor en la parada militar obedecía a razones de representación institucional de las Fuerzas Armadas en un acto religioso, debió respetarse el principio de voluntariedad en la asistencia y, por tanto, atenderse a la solicitud del actor de ser relevado del servicio, en tanto que expresión legítima de su derecho de libertad religiosa". De lo cual se deduce que cuando los poderes del Estado obligan a sus miembros a participar en actos o ceremonias oficiales de contenido religioso, están vulnerando el derecho de libertad religiosa y de culto de las personas que integran las instituciones públicas. Y a FJ 9 añade que la libertad religiosa «garantiza la existencia de un claustro íntimo de creencias y, por tanto, un espacio de autodeterminación intelectual ante el fenómeno religioso, vinculado a la propia personalidad y dignidad individual». Asimismo, que junto a esta dimensión interna, la libertad religiosa: "incluye también una dimensión externa de agere licere que faculta a los ciudadanos para actuar con arreglo a sus propias convicciones y mantenerlas frente a terceros".

Posteriormente, el Pleno del Tribunal Constitucional, en la sentencia 154/2002, de 18 de julio, manifestó en el fundamento 9 que este reconocimiento de un ámbito de libertad y de una esfera de agere licere lo es «con plena inmunidad de coacción del Estado o de cualesquiera grupos sociales» y se complementa, en su dimensión 
negativa, por la prescripción del art. 16.2 CE de que «nadie podrá ser obligado a declarar sobre su ideología, religión o creencias». Agrega que la dimensión externa de la libertad religiosa se traduce además «en la posibilidad de ejercicio, inmune a toda coacción de los poderes públicos, de aquellas actividades que constituyen manifestaciones o expresiones del fenómeno religioso», tales como las que se relacionan en el art. 2.1 de la Ley Orgánica 7/1980 de libertad religiosa, a los actos de culto, enseñanza religiosa, reunión o manifestación pública con fines religiosos, y asociación para el desarrollo comunitario de este tipo de actividades.

En la Sentencia 131/2013, de 5 de junio de 2013, recurso de inconstitucionalidad 17252002, sobre nulidad de la exención del requisito de ley de reconocimiento para las universidades fundadas por la Iglesia católica, el Pleno del Tribunal Constitucional en el fundamento 20 concluye que la decisión del legislador de establecer dicha excepción entraña una real y efectiva diferencia de trato entre las Universidades privadas en razón de que hayan sido creadas o no por la Iglesia católica. Precisando que no toda desigualdad de trato legislativo en la regulación de una materia entraña una vulneración del derecho fundamental a la igualdad ante la Ley del artículo 14 C.E., sino únicamente aquellas que introduzcan una diferencia de trato entre situaciones que puedan considerarse sustancialmente iguales y sin que posean una justificación objetiva y razonable. Diferencia que en este caso carece de la justificación objetiva y razonable que toda diferenciación normativa debe poseer para ser considerada legítima.

De acuerdo a dicha jurisprudencia del Alto Tribunal español, el art. 16.3 consagra el principio de laicidad y, por tanto, es perfectamente legítimo afirmar que el español es un Estado laico. Son varias sentencias en las que se considera equivalentes los términos de aconfesionalidad y laicidad ${ }^{22}$.

\subsubsection{Jurisprudencia del Tribunal Europeo de Derechos Humanos}

El Tribunal Europeo de Derechos Humanos (TEDH), protege los derechos proclamados en el Convenio para la Protección de Derechos Humanos y de las Libertades Fundamentales, de Roma de 1950, así como por sus protocolos ${ }^{23}$, de acuerdo con el artículo 35 ídem, correspondiéndole declarar en última instancia las violaciones de los derechos protegidos en dicho instrumento luego de haberse agotado las jurisdicciones internas de los respectivos Estados europeos.

22 LlAMAZARES FERNÁNDEZ, Dionisio. Libertad de conciencia y laicidad en las instituciones y servicios públicos. Editorial Dykinson, Madrid, 2005, p. 9.

23 El Protocolo Adicional al Convenio para la Protección de los Derechos Humanos y de las Libertades Fundamentales, Protocolo No 1, establece en el Art. 2: “A nadie se le puede negar el derecho a la educación y que el Estado deberá respetar el derecho de los padres a que la enseñanza que reciben sus hijos se imparta conforme a sus convicciones religiosas y filosóficas". 
En cuanto a la protección del derecho consagrado en el artículo 9 del Convenio, que comprende la libertad de religión, es preciso tener en consideración el criterio del margen de apreciación con el cual el TEDH realiza un juicio de ponderación, lo cual es de gran relevancia dado que no todos los Estados europeos proclaman el principio de laicidad ${ }^{24}$. De la jurisprudencia del Tribunal de Estrasburgo citaremos, entonces, aquellos casos que ilustran los alcances del derecho a la libertad de religión y del principio de laicidad estatal, aunque matizadas por el criterio jurisprudencial del margen de apreciación.

El TEDH, en el caso Buscarini y otros contra San Marino, de 1999, controversia suscitada por la aplicación de la legislación de la República de San Marino -que exigía como condición previa para acceder a los cargos o puestos públicos, prestar un juramento sobre los Evangelios-, condenó a San Marino considerando que "... requerir a los demandantes prestar juramento sobre los Evangelios era equivalente a requerir a dos representantes electos del pueblo jurar adhesión a una particular religión, un requerimiento que es incompatible con el artículo 9 del Convenio" (párrafo 39). Declarando la existencia de esta violación al Convenio, el Tribunal protegió al individuo frente a una amenaza de coacción estatal, sosteniendo que el interés del Estado en exigir una manifestación externa de lealtad o en mantener sus tradiciones cristianas encuentra su límite en la conciencia de los individuos ${ }^{25}$. Con esta jurisprudencia, puede afirmarse que la presencia de símbolos religiosos en los actos de toma de posesión de cargos o funcionarios públicos representa una vulneración del derecho a la libertad de conciencia y, por otra, supone la ruptura de las reglas del Estado democrático y, por lo tanto, del principio de laicidad ${ }^{26}$.

En el primer caso donde el Tribunal falla sobre símbolos religiosos en los colegios públicos, caso Lautsi y otros contra Italia, decisión del 3 de noviembre de 2009, la Sala inicialmente (por unanimidad) le dio la razón a la ciudadana italiana que solicitó el retiro de los crucifijos de las aulas del instituto público donde estudiaban sus hijos, bajo la consideración de que la exposición de simbología relacionada con el catolicismo (confesión mayoritaria en las aulas) en los salones de clase de escuelas públicas es contrario al pluralismo educativo que resulta esencial para la preservación de una sociedad democrática. Dicha sentencia fue con posterioridad desconocida por la Gran Sala del TEDH en sentencia del 18 de marzo de 2011, que en votación

24 OROZCOSOLANO, Víctor Eduardo. Op. cit., p. 159.

25 ARLETTAZ, Fernando. La jurisprudencia del Tribunal Europeo de Derechos Humanos sobre la libertad religiosa: un análisis jurídico-político, en Revista Derechos y Libertades, Número 27, Época II, junio 2012, Instituto de Derechos Humanos Bartolomé de las Casas, España, p. 215, en http://earchivo.uc3m.es/bitstream/handle/10016/19585/DyL-2012-27-arlettaz.pdf?sequence=1 (consultada el 14-01-2016).

26 CONTRERAS MAZARÍO, José M. ${ }^{\text {y }}$ CELADOR ANGÓN. Óscar. Laicidad, manifestaciones religiosas e instituciones públicas. Fundación Alternativas. Documento de trabajo 124/2007, p.38, en http://www.fundacionalternativas.org/public/storage/laboratorio_documentos_archivos/xmlimport5d6eWX.pdf (consultada el 10-02-2016). 
dividida consideró que la utilización de simbología religiosa en las aulas no lesiona los derechos proclamados por el Convenio Europeo para la Protección de los Derechos Humanos y de las Libertades Fundamentales. Aquí puede apreciarse que el criterio del margen de apreciación utilizado por el Tribunal Europeo de Derechos Humanos para valorar estos asuntos, en el fondo le ha servido para relativizar el contenido y el alcance de estos derechos, pese a la existencia del pluralismo religioso que se verifica en el escenario europeo, que reclama protección por parte del ordenamiento jurídico27.

El pluralismo, en situaciones de desequilibrio como la del caso examinado, exigiría del artículo 14 del Convenio de Roma otro tipo de acción, una limitación de la preponderancia de la mayoría, tanto porque se haga pasar por universalismo que porque se presente como una identidad colectiva homogénea. El pluralismo exigiría al principio antidiscriminatorio que conteste el privilegio que la posición hegemónica del grupo mayoritario consigue disfrazar de simple "alteridad". La Sentencia definitiva de 2011 acogió finalmente el argumento que construía el privilegio de la mayoría como simple alteridad, restringiendo así la función del principio antidiscriminatorio en la relación entre laicidad, libertad religiosa e igualdad ${ }^{28}$.

En el caso Bayatyan contra Armenia, sobre objeción de conciencia al servicio militar obligatorio, art. $9^{\circ}$ del Convenio de Roma, libertad de pensamiento, de conciencia y de religión; Bayatyan objetó el servicio militar y ofreció estar dispuesto a prestar servicio militar alternativo; siendo arrestado y condenado a prisión en base a la legislación de Armenia según la cual el servicio militar es obligatorio para todos los varones a partir de los dieciocho años de edad. Inicialmente el TEDH estableció que la objeción de conciencia al servicio militar no está protegida por art. $9^{\circ}$ del Convenio, a lo que el recurrente acude a la Gran Sala que por falló del 7 de julio del 2011 declaró que ha habido violación del artículo $9^{\circ}$ de la Convención en el caso de una condena al negarse a realizar el servicio militar por motivos de conciencia, y que el Estado responsable, Armenia, está obligado a pagar al accionante la suma de 10,000 euros por concepto de daño no pecuniario, y al pago de 10,000 euros por concepto de costas y expensas. Es el primer caso donde el TEDH reconoció que el citado art. $9^{\circ}$ protegía el derecho de objeción de conciencia, categorizando el mismo como derecho fundamental y generando precedente jurisprudencial para los países miembros del Consejo Europeo. La Gran Sala determinó, en el Ap. 110, que "la oposición al servicio militar, cuando está motivada por un conflicto grave e insuperable entre la obligación de servir en el ejército y la conciencia de una persona en la que sus convicciones sinceras y profundas, de naturaleza religiosa u otra, constituyen una convicción que alcanza un grado suficientemente fuerte, serio, coherente e importante para implicar las garantías del artículo 9".

27 OROZCOSOLANO, Víctor Eduardo, Op. cit., p. 175.

28 MORONDOTARAMUNDI, Dolores, Op. cit, p. 605. 
Bajo dicho razonamiento, es factible argumentar de forma razonable que un derecho a la objeción de conciencia al servicio militar puede derivar del derecho a la libertad de conciencia y de religión. La sentencia del TEDH supuso un cambio doctrinal acerca de la naturaleza de la objeción de conciencia, la cual pasó de ser considerada una excepción puntual a una obligación impuesta por el Derecho positivo, a valorarse como una genuina manifestación del derecho fundamental a la libertad de conciencia. Dicho cambio en la posición del TEDH fue posible sobre la base de la "doctrina del instrumento vivo" y la existencia de un amplio reconocimiento de la objeción al servicio militar en los Estados europeos y en el Derecho internacional. De acuerdo a la doctrina del instrumento vivo que desarrolla la Corte (Aps. 101 y 102), el Convenio Europeo de Derechos Humanos se aplica como un instrumento vivo que no puede entenderse fosilizado. Así, el mismo debe interpretarse "a la luz de las condiciones de vida actuales y las concepciones que prevalecen actualmente en los Estados democráticos" 29 . Asimismo, la sentencia refuerza su posición en el Derecho comparado, en los distintos foros internacionales sobre derechos humanos e instrumentos internacionales que han evolucionado reconociendo la objeción de conciencia al servicio militar, es decir, en cuanto a la vinculación de la objeción de conciencia y la libertad ideológica y de conciencia.

El caso Folgero y otros contra Noruega, sentencia del 29 de junio de 2007, se analiza si el Estado demandado, al cumplir las funciones asumidas en materia de educación y de enseñanza, veló por que las informaciones o conocimientos que figuran en el programa de estudios de la asignatura de KRL fuesen difundidas de manera objetiva, crítica y pluralista o si la finalidad perseguida era un adoctrinamiento que no respetaba las convicciones religiosas y filosóficas de los padres demandantes, transgrediendo así el límite que se deduce implícitamente del artículo 2 del Protocolo número 1. El Tribunal de Estrasburgo concluyó que existió vulneración del citado protocolo, pues se evidenció que el programa de la signatura, el cristianismo, su fe, su moral, sus principios, contenía una cláusula de vocación cristiana y tenía por objetivo el estudio profundo de dichos temas, además de estar previstas actividades de rezo y otras, y solo se estipulaba el avocamiento superficial al estudio de las demás religiones y creencias filosóficas. En opinión de Hurtado ${ }^{30}$, desde el momento que se

29 RUIZ BURSÓN, Francisco Javier. "Novedades desde Estrasburgo sobre la objeción de conciencia”. Revista General de Derecho Canónico y Derecho Eclesiástico del Estado, 31, 2013, p. 9. El autor concluye, sobre la objeción de conciencia, que según la doctrina de esta sentencia, deben darse una serie de requisitos para que este derecho se incardine en la libertad de conciencia: una convicción seria, sincera y coherente del objetor y un conflicto profundo e insuperable con la obligación impuesta por una norma legal; en www.unav.edu/matrimonioyfamilia/observatorio/uploads/30677_Ruiz_RGDCDEE2013_Novedades. pdf (consultada el 21-01-2016).

30 Hurtado Huailla, Ana Cecilia. Análisis jurisprudencial del derecho a la libertad religiosa. Centro de Estudios de Derecho Penal Económico y de la Empresa, 2015, en http:/ / www.cedpe.com/blogs/Delitos_empresariales_y_derecho_procesal/?p=22 (consultada el 15-1215). 
considera una "obligación general" el hecho de llevar la asignatura KRL de contenido profundo sobre el cristianismo y superficial sobre otras religiones, se afecta el derecho que tienen los padres a que sus hijos reciban las enseñanzas de acuerdo a sus convicciones religiosas y/o filosóficas, más aún si ello implica también aprender de memoria rezos, participar en ritos y cultos. Asimismo, al exigirse a efectos de lograr una exención parcial de la asignatura, que se declare sobre la creencia religiosa que se profesa, se estaría vulnerando una de las manifestaciones de la libertad religiosa, que consiste en no declarar sobre las creencias profesadas, que forman parte del claustro íntimo de la persona.

En síntesis, puede afirmarse que la jurisprudencia del Tribunal Europeo de Derechos Humanos ha venido evolucionando en su concepción sobre la vinculación de la libertad de conciencia, la libertad ideológica y la libertad religiosa, otorgando reconocimiento y protección al contenido esencial de dichos derechos; así como desarrollando el alcance de las posibles restricciones al ejercicio de la libertad religiosa, tomando en consideración el criterio del margen de apreciación de los Estados nacionales europeos y el principio de laicidad del Estado.

\subsubsection{Sobre el criterio del «margen de apreciación»}

Con lo observado en la interpretación jurisprudencial realizada por el Tribunal de Estrasburgo respecto a la libertad religiosa, queda claro que esta proyecta su contenido en una doble dirección: interna y externa. El primero referido a la libertad de creencias de cada persona, que no admite ninguna limitación que pueda ser legítimamente ejercida en su contra, $y$, la segunda que equivale a la libertad de manifestarla -individual o colectivamente-, que supone afecciones al espacio público y que se traduce en prácticas o manifestaciones como la apariencia física, la observancia de determinados regímenes alimenticios, el uso de determinadas vestimentas, las demostraciones religiosas públicas, la enseñanza de la religión, los actos rituales asociados a ciertos momentos vitales, o el uso de una determinada lengua ritual. Sin embargo, el Tribunal Europeo de Derechos Humanos ha reconocido que no es posible discernir una concepción unitaria de la religión en las sociedades europeas, y que el impacto de las manifestaciones externas de las creencias religiosas varía según el tiempo y el contexto ${ }^{31}$.

Ahora bien, el TEDH ha legitimado varias restricciones a la libertad de manifestar la propia religión basándose en conceptos indeterminados -como el orden público, la moral pública- o en conflictos de derechos, prohibiendo determinadas vestimentas con significado religioso en instituciones educativas, o de la práctica del sacrificio de animales conforme a un rito específico, del mismo modo que no ha justificado la

31 RUIZ VIEYTEZ, Eduardo J. "La diversidad religiosa en el País Vasco: carencias y propuestas sobre su tratamiento jurídico e institucional", en E. Ruiz (coord.): La diversidad religiosa en el País Vasco. Nuevos retos sociales y culturales para las políticas públicas. Bilbao, Universidad de Deusto, 2011, p. 128. 
ausencia del lugar de trabajo por festividades religiosas. En muchos casos la clave de la interpretación jurídica se refiere al alcance posible a las restricciones a la libertad de religión fundadas en motivos presuntos de seguridad, laicidad, $\mathrm{u}$ orden $\mathrm{u}$ salud pública. Podríamos concluir que la jurisprudencia de Estrasburgo, que en esta materia concede gran importancia al llamado "margen de apreciación nacional", se sitúa en una suerte de punto intermedio entre la laicidad abierta y laicismo rígido, posiblemente reflejando las posturas contradictorias a su vez de los distintos países europeos $^{32}$.

El criterio del margen de apreciación aboga por reconocer a las autoridades estatales un ámbito para apreciar la necesidad de ciertas medidas restrictivas; lo que comporta, respecto al derecho a la libertad religiosa, una aplicación particular del Convenio de Roma según las circunstancias del caso. Los tribunales realizan, en tal cometido, un juicio de ponderación entre las normas del Convenio y las Constituciones, las circunstancias políticas, económicas y culturales de cada uno de los Estados miembros. De esa manera, se ha ido perfilando en qué sentido debe ser concebido el Convenio de Roma en esta materia o cuál es la dirección a la que se debe llegar para uniformar los alcances de la libertad de religión, que encuentra en el principio de laicidad la otra cara de la moneda, es decir, el presupuesto necesario para tolerar el pluralismo religioso ${ }^{33}$.

Ello es así, por cuanto como se ha referido anteriormente, si bien el principio de laicidad se presenta como un valor superior del ordenamiento jurídico, dicho principio no es inmutable sino variable en función de los movimientos sociales, culturales y políticos, del momento; es decir, en función del marco concreto de laicidad de un determinado Estado y de las dinámicas que pueden condicionar el funcionamiento de los mecanismos de separación Estado-Iglesia. Ante los frecuentes conflictos, por ejemplo, entre las diferentes confesiones religiosas en lo atinente a la igualdad religiosa, se deben distinguir las relativas posiciones de "poder" entre los grupos, a efecto de que el ejercicio de la libertad religiosa se concrete dentro de un marco de igualdad, sin subordinaciones o exclusiones de otros grupos, que afecten el principio antidiscriminatorio y el pluralismo religioso. De acuerdo a dicho margen de apreciación, entonces, los Estados pueden evaluar si tras las formaciones religiosas predominantes no se ocultan formas de poder históricamente consolidadas que excluyen a otras religiones, o si por el contrario se trata de expresiones culturales que, no obstante estar ampliamente extendidas entre la población, su sola presencia y trascendencia histórica no comprometen el derecho individual a la libertad de conciencia y a la libertad religiosa.

32 Ibíd., p., 130.

33 OROZCOSOLANO, Víctor Eduardo. Op. cit., p. 160. 
Se trata, ciertamente, de una delgada línea sobra la que pueden transitar diferentes concepciones sobre la laicidad, pero que necesariamente se debe trazar si se han dejar atrás privilegios y compromisos heredados del pasado confesional del Estado. Los tan sonados casos sobre la presencia de símbolos religiosos en las dependencias del Estado grafican la complejidad de establecer, en base al criterio de apreciación, los alcances de los derechos en juego. De ahí que sea necesario se consideren los límites a la libertad de religión, que puede ser razonablemente restringida para tutelar los derechos de terceros y el orden público, así como sus garantías jurisdiccionales; de forma que el juicio de ponderación se constituye en una herramienta indispensable para asegurar su aplicación frente a otros derechos y libertades fundamentales.

En el ámbito latinoamericano, dado el carácter subsidiario ${ }^{34}$ de la Corte Interamericana de Derechos Humanos, por ser los Estados los principales obligados en el cumplimiento de las obligaciones negativas y positivas derivadas de la convención, el margen de apreciación debe ser admitido como un ámbito de deferencia reconocido a los Estados. De modo que el margen de apreciación actúa como un margen de discreción en la determinación de la ejecución de las obligaciones contenidas en el tratado y la limitación de los derechos, en cuanto a la apreciación de los motivos bajos los cuales se justificaría esto ${ }^{35}$.

Ello no significa que exista una facultad discrecional absoluta de los Estados para limitar sin control los derechos fundamentales protegidos por la convención. El margen de apreciación no puede ser tan amplio que suponga un impedimento para el disfrute sin discriminación de los derechos consagrados por la Convención Americana sobre Derechos Humanos. No se trata de dejar a los Estados la determinación del contenido del principio de igualdad y no discriminación, como tampoco determinar cuándo es posible distinguir o no distinguir. La cuestión sería que el examen de dicha apreciación sería rígido si afectase a categorías protegidas como la religión, la raza, la orientación sexual, el género, el sexo, el origen, nacionalidad, entre otras. Evidentemente, el Estado debe identificar las distinciones y los supuestos que justifican la distinción, pero si no es razonable en base a razones preponderantes y/o de un alto peso, entonces, se entiende que la medida sería discriminatoria, excediendo así el Estado su margen de apreciación ${ }^{36}$.

34 El carácter subsidiario radica, en que la Corte IDH no está supuesta a actuar de manera principal o que reemplace a las autoridades nacionales en el cumplimiento de sus obligaciones al amparo de la CADH.

35 REYES-TORRES, Amaury A. Una cuestión de apreciación: el margen de apreciación en la Corte Interamericana de los Derechos Humanos, 2015, p. $\quad$ p. https://www.academia.edu/10416869/Una_cuesti\%C3\%B3n_de_apreciaci\%C3\%B3n_El_margen_de_a preciaci\%C3\%B3n_en_la_Corte_Interamericana_de_los_Derechos_Humanos (consultada el 15-01-16).

36 Ibíd., p. 28. 


\subsection{En el constitucionalismo latinoamericano}

Si bien las primeras repúblicas latinoamericanas que obtuvieron su independencia política de España no nacieron como naciones laicas -redactando constituciones donde se protegía y privilegiaba a la Iglesia Católica Romana y no se toleraba la presencia de otras confesiones-, algunos países llevaron a cabo una separación formal entre el Estado y las Iglesias. Tal el caso de Colombia en 1853, México en 1857, Brasil en 1890 y posteriormente Panamá en 1904, Ecuador en 1906, Uruguay en 1916, Honduras en 1924, Chile en 1925, o Cuba en 1940. De cualquier manera, entre 1880 y 1930 en la mayor parte de los países latinoamericanos que antes no habían conocido reformas liberales o no las habían conservado, se dieron casi simultáneamente regímenes liberales que impusieron medidas laicistas, como la eliminación del pago forzoso del diezmo, la nacionalización de bienes eclesiásticos, el establecimiento del registro civil de nacimientos o del matrimonio como contrato civil, la secularización de los cementerios e incluso como ya se vio, en algunos casos, la formal separación entre el Estado y la Iglesia ${ }^{37}$.

Sin embargo, habría que esperar hasta las últimas dos décadas del siglo XX y principios del nuevo milenio, a que tres factores permitieran la reactivación de la laicidad: 1) la gestación de una efectiva y significativa pluralidad religiosa; 2) la mayor conciencia de la necesidad de proteger los derechos humanos y por lo tanto los derechos de minorías en la crecientemente reconocida diversidad, y; 3) la gradual pero real democratización de las sociedades latinoamericanas ${ }^{38}$. Y puede decirse que "Todas las Constituciones latinoamericanas admiten la libertad de conciencia y de culto, uno de los elementos de la laicidad fundacional"39; por lo que cabe afirmar que el constitucionalismo latinoamericano viene evolucionando hacia la consagración del principio de laicidad del Estado.

De otro lado, está el Sistema Interamericano de Protección de los Derechos Humanos, que cuenta con instrumentos como la Carta de la Organización de los Estados Americanos de 1948, donde si bien no existe una disposición expresa sobre el derecho de libertad religiosa, en su artículo 3ro, inciso k) establece que: "Los Estados Americanos proclaman los derechos fundamentales de la persona humana sin hacer distinción de raza, nacionalidad, credo, o sexo". Similarmente, la Declaración Americana sobre Derechos y Deberes del Hombre de 1948, no obstante carecer de efectos jurídicos vinculantes, en el art. II declara: "Todas las personas son iguales ante la ley y tienen los derechos y deberes consagrados en esta declaración, sin distinción de raza, sexo, idioma, credo, ni otra alguna"; y

37 BlanCARTE, Roberto. América Latina. Entre pluri-confesionalidad y laicidad, Civitas, Porto Alegre, v. 11, n. 2, maio-ago. 2011, p. $199, \quad$ en http://revistaseletronicas.pucrs.br/ojs/index.php/civitas/article/viewFile/9644/6738 (consultada el 291-2016).

38 Ibíd, p. 203.

39 PRECHT PIZARRO, Jorge Enrique. "La laicidad del Estado en cuatro Constituciones Latinoamericanas". Estudios constitucionales, noviembre, año/vol. 4, número 002, 2006, p. 699. 
sobre la libertad religiosa, en su art. III: "Toda persona tiene el derecho de profesar libremente una creencia religiosa y de manifestarla y practicarla en público y en privado".

A su vez, en 1969 los Estados suscriptores de la Convención Americana sobre Derechos Humanos (Pacto de San José), han convenido en su art. $1^{\circ}$ que se comprometen a respetar los derechos y libertades reconocidos en ella y a garantizar su libre y pleno ejercicio a toda persona que esté sujeta a su jurisdicción, sin discriminación alguna por motivos de religión, entre otros, y establece en el art. 12 los alcances de los derechos a la libertad de conciencia y de religión:

"1. Toda persona tiene derecho a la libertad de conciencia y de religión. Este derecho implica la libertad de conservar su religión o sus creencias, o de cambiar de religión o de creencias, así como la libertad de profesar y divulgar su religión o sus creencias, individual o colectivamente, tanto en público como en privado.

2. Nadie puede ser objeto de medidas restrictivas que puedan menoscabar la libertad de conservar su religión o sus creencias o de cambiar de religión o de creencias.

3. La libertad de manifestar la propia religión y las propias creencias está sujeta únicamente a las limitaciones prescritas por la ley y que sean necesarias para proteger la seguridad, el orden, la salud o la moral públicos o los derechos o libertades de los demás.

4. Los padres, y en su caso los tutores, tienen derecho a que sus hijos o pupilos reciban la educación religiosa y moral que esté de acuerdo con sus propias convicciones."

En ese contexto, la protección de los derechos a la libertad de conciencia y libertad de religión en el ámbito de la OEA, una vez agotada la jurisdicción interna de los respectivos Estados, reside en manos de la Corte Interamericana de Derechos Humanos. La jurisprudencia de la Corte, en ese sentido, ha sido clara al recordar en la sentencia del 4 de septiembre de 2012, caso Masacres de Río Negro versus Guatemala, que: "la Convención Americana, en su artículo 12, contempla el derecho a la libertad de conciencia y religión, el cual, según la jurisprudencia de este Tribunal, permite que las personas conserven, cambien, profesen y divulguen su religión o sus creencias. Este derecho es uno de los cimientos de la sociedad democrática. En su dimensión religiosa, constituye un elemento trascendental en la protección de las convicciones de los creyentes y en su forma de vida" (párr. 154). La Corte ratificó, con dicha sentencia, el criterio que previamente ya había establecido en el caso "La Última Tentación de Cristo", caso Olmedo Bustos y otros versus Chile, por sentencia del 5 de febrero de 2001 (párr. 79). 


\subsection{Estado de la cuestión en el Perú}

\subsubsection{Antecedentes sobre la cuestión religiosa}

En el régimen de colaboración, el Estado reconoce a la Iglesia Católica su competencia en los asuntos espirituales y regula sus relaciones por Concordatos escrupulosamente observados; y el régimen de unión ha sido mantenido en su texto y su espíritu en todas las constituciones de la República ${ }^{40}$; debiendo precisarse que dicho régimen de unión continuo hasta antes de la entrada en vigencia de la Constitución de 1979.

La de 1823 declaraba que "la Religión de la República es la Católica, Apostólica y Romana, con exclusión del ejercicio de cualquier otra. Es un deber de la nación protegerla constantemente por todos los medios conforme al espíritu del Evangelio y el de cualquier habitante del Estado respetarla inviolablemente (arts. $8^{\circ}$ y $9^{\circ}$ ). La de 1826 contenía una declaración más breve: "La Religión del Perú es la Católica Apostólica y Romana" (art. 6). Los textos de la de 1828, 1834 y 1856 son idénticos: "La Religión Católica es la Religión oficial de la República y el Estado la protege por todos los medios, conforme al espíritu del Evangelio y no permite el ejercicio de otra" (art. $3^{\circ}$ de la Constitución de 1828 , art. $2^{\circ}$ de la de 1834 y art. $4^{\circ}$ de la 1856). En la Carta de 1839, se expresaba que "su religión es la Católica, Apostólica y Romana, sin permitir el ejercicio público de cualquier otro culto" (art. 3º). Las de 1860 y de 1920 incluían una declaración igual: "La Nación profesa la Religión Católica, Apostólica y Romana. El Estado la protege" (art. 4 de la de 1860 y art. $5^{\circ}$ de la de 1920). La de 1933 disponía en su artículo $232^{\circ}$ que "respetando los sentimientos de la mayoría nacional, el Estado protege a la religión Católica, Apostólica y Romana"41.

\subsubsection{Recepción del derecho fundamental a la libertad religiosa en el Perú}

Con las Constituciones de 1979 y 1993 se configura ya la libertad religiosa como un derecho fundamental de la persona; así, la Constitución de 1979 señala en el art. 2 inc. 2 que toda persona tiene derecho: "A la igualdad ante la ley, sin discriminación alguna por razón de sexo, raza, religión, opinión e idioma...". Y al momento de referirse a las relaciones del Estado con la Iglesia, en el art. $86^{\circ}$, que "Dentro de un régimen de independencia y autonomía, el Estado reconoce a la Iglesia Católica como elemento importante en la formación histórica, cultural y moral del Perú. Le presta su colaboración. El Estado puede también establecer formas de colaboración con otras confesiones".

Con muy ligeras variaciones, en el Título I, Capítulo I sobre los derechos fundamentales de la persona, la Carta Política vigente de 1993 en su art. $2^{\circ}$, inciso $2^{\circ}$, reconoce que toda persona tiene derecho: "A la igualdad ante la ley. Nadie debe ser

40 PAReja PAZ SOLDÁn, José. Derecho Constitucional peruano y la Constitución de 1979. Justo Valenzuela V., Lima,1980, p. 499.

41 Ibíd, p.500. 
discriminado por motivo de origen, raza, sexo, idioma, religión, opinión, condición económica o de cualquiera otra indole"; ratificando de esa manera el principio de igualdad de las personas ante la ley. Y, en el inciso 3 del mismo artículo, el derecho: "A la libertad de conciencia y de religión, en forma individual o asociada. No hay persecución por razón de ideas o creencias. No hay delito de opinión. El ejercicio público de todas las confesiones es libre, siempre que no ofenda la moral ni altere el orden público"; ratificando así el principio de libertad religiosa en nuestro país.

La educación, punto álgido en las relaciones con la Iglesia, es prevista en el art. $14^{\circ}$, tercer párrafo, estableciendo como presupuesto que: "La educación religiosa se imparte con respeto a la libertad de las conciencias". En cuanto a la relación Estado-Iglesia en sí, en su art. 50 la Carta de 1993 dispone en el primer párrafo que: "Dentro de un régimen de independencia y autonomía, el Estado reconoce a la Iglesia Católica como elemento importante en la formación histórica, cultural y moral del Perú, y le presta su colaboración". Y en el segundo párrafo: "El Estado respeta otras confesiones y puede establecer formas de colaboración con ellas".

De otro lado, el Perú es país suscriptor de diversos instrumentos internacionales, como la Declaración Universal de Derechos Humanos, cuyo artículo $18^{\circ}$ prescribe que: "Toda persona tiene derecho a la libertad de pensamiento, de conciencia y de religión; este derecho incluye la libertad de cambiar de religión o de creencia, así como la libertad de manifestar su religión o su creencia, individual y colectivamente, tanto en público como en privado, por la enseñanza, la práctica, el culto y la observancia". Y en casi idénticos términos, así se recoge en el artículo $18^{\circ}$, numeral 1 del Pacto Internacional de Derechos Civiles y Políticos de 1966.

Se cuenta también con la ya citada Convención Americana sobre Derechos Humanos de 1969, cuyo art. $12^{\circ}$ desarrolla en cuatro incisos el derecho de libertad de conciencia y de religión. Estas normas -a las que habría que sumar la Carta de la Organización de los Estados Americanos y la Declaración Americana sobre Derechos y Deberes del Hombre-, son los referentes internacionales que protegen el derecho a la libertad de conciencia y a la libertad religiosa en el Perú, y que nuestro derecho interno los cataloga como derechos fundamentales de la persona, lo cual asegura tanto su protección interna como externa.

\subsubsection{La Ley $\mathrm{N}^{\circ} 29635$, ley de libertad religiosa y su reglamento}

La Ley 29635, Ley de Libertad Religiosa, del 2010, dedica quince artículos, cuatro Disposiciones Complementarias Finales y una Disposición Complementaria Transitoria, a regular la libertad religiosa, como desarrollo de la Constitución Política vigente, de conformidad con los Tratados Internacionales ratificados por el Estado peruano, precisando que: "El Estado garantiza el derecho fundamental de toda persona a la libertad de religión reconocido y amparado por la Constitución Política del Perú y por los Tratados Internacionales ratificados por el Estado peruano"; según reza el primer párrafo 
de su artículo $1^{\circ}$, y en su segundo párrafo que: "El ejercicio público y privado de este derecho es libre y tiene como único limite tanto la protección del derecho de los demás al ejercicio de sus libertades públicas y derechos fundamentales como la protección del orden, la salud y moral públicos".

Al estar vinculada la libertad religiosa al derecho a la igualdad ante la Ley, el Artículo $2^{\circ}$ prohíbe toda acción $\mathrm{u}$ omisión que discrimine a una persona en razón de sus creencias religiosas, y en un segundo párrafo que el Estado reconoce la diversidad de las entidades religiosas; gozando de los mismos derechos, obligaciones y beneficios. No obstante, al desarrollar en el Artículo $3^{\circ}$ el ejercicio individual de la libertad de religión, en el literal c. el Estado abandona su posición de neutralidad respecto a la Iglesia, sancionando el derecho a: "Recibir asistencia religiosa por su confesión. Las instituciones públicas competentes adoptan las medidas y normas necesarias para facilitar la asistencia religiosa en el ámbito de las Fuerzas Armadas y de la Policía Nacional del Perú, en las prisiones, en los centros públicos hospitalarios, asistenciales y otros bajo su dependencia". De esa manera, desarrollando en el precitado dispositivo un laicismo positivo, el Estado se encontraría eventualmente en la obligación o deber de facilitar la asistencia religiosa de personas en situaciones de dependencia, adoptando para tal fin las medidas necesarias e incluso dictar normas internas promocionales de la asistencia religiosa; actividades que no necesariamente se condicen con la función pública, pero en las que el Estado se vería en la situación de participar para asegurar su cumplimiento. Bajo tal contexto, el asistencialismo religioso al interior de las instituciones públicas se prestaría a la práctica del proselitismo de grupos religiosos tan común en nuestro medio-, que se disputan la ocasión de prestar estos servicios.

De otro lado, el literal f. del art. $3^{\circ}$, al regular el derecho a conmemorar las festividades y guardar el día de descanso que cada persona considere sagrado en su religión, se señala que dicha situación se da "debiéndose armonizar los derechos de los trabajadores con los de la empresa o administración pública para la que labore, y de los estudiantes con las instituciones educativas, conforme al reglamento de la presente Ley". Sobre el punto cabe cuestionarse qué debe entenderse en la ley bajo comento por "derechos de la administración pública", en este ámbito de relación, aspecto que no se esclarece, limitándose a señalar que han de armonizarse conforme al reglamento de la presente ley.

Respecto al art. $4^{\circ}$, que regula la objeción de conciencia, la define como la "oposición de un individuo al cumplimiento de un deber legal, en razón de sus convicciones morales o religiosas"; y en un segundo párrafo indica que "se ejerce cuando alguien se ve imposibilitado de cumplir una obligación legal por causa de un imperativo, moral o religioso, grave o ineludible, reconocido por la entidad religiosa a la que pertenece". Esta definición de la objeción de conciencia es cuestionada por errónea, a 
decir de Huaco ${ }^{42}$, pues esta no puede oponerse solamente ante un deber u obligación legal sino también frente a un deber constitucional, es decir, ante un "deber $u$ obligación jurídica"; asimismo, porque existen objeciones de conciencia que no se basan en convicciones religiosas sino en objeciones humanistas o filosóficas, por lo que no solo se puede objetar por razones religiosas; definición que es discriminatoria contra los no creyentes.

Ahora bien, la ley fue posteriormente reglamentada por el Decreto Supremo $\mathrm{N}^{\circ} 010$ 2011, del 26 de julio del 2011, y respecto a los puntos tratados el reglamento no ofrece mayor desarrollo. El art. $4^{\circ}$ del reglamento, sobre el ejercicio individual de la libertad religiosa, señala que la mención de derechos contemplada en el artículo $3^{\circ}$ de la Ley es de naturaleza enunciativa y en ningún modo podrá interpretarse de manera restrictiva; y concretamente sobre el tema de la asistencia religiosa en las entidades públicas (art. $5^{\circ}$ ), solo se verá restringida la misma, impidiéndose el acceso de la entidad religiosa al local institucional, "si contravienen las normas de interés público o internas de la institución que autorizó el ingreso, o si se cancela la inscripción de la entidad religiosa en el registro del Ministerio de Justicia".

Y en cuanto a las fiestas de guardar y el día de descanso en el ámbito laboral, según el art. $6^{\circ}$ del reglamento la administración pública debe garantizar el ejercicio de este derecho, siempre que "no resulte incompatible con la organización social del trabajo y se garantice el cumplimiento de la jornada laboral a que se refiere la normatividad vigente". Norma que advertimos de poca o nula eficacia si consideramos que los días de descanso religioso interrumpen, precisamente, la jornada laboral mientras duren las celebraciones jubilares.

Asimismo, en el art. $10^{\circ}$ del Reglamento, se establece que "los actos de culto público se realizan de manera ordinaria en los inmuebles o locales destinados para dicho fin"; sin hacer la norma la menor restricción respecto a los inmuebles del Estado, donde en virtud al principio de laicidad los mismos deberían estar ajenos a las actividades de culto público religioso. En tal sentido, es de observar que una prescripción legal de tal naturaleza resulta permisiva, pues convalida la irregular utilización de los locales públicos para el culto religioso -práctica que se constata en nuestro medio- o se traduce en la creación dentro de las dependencias estatales de espacios o locales destinados al culto ${ }^{43}$ o para la ubicación de imágenes e iconografía particulares de

42 Huaco Palomino, Marco. Lo bueno, lo malo y lo feo de la ley de libertad religiosa: Texto íntegro de la ley y comentario, 2010, en http:/ / www.marcohuaco.com/mh/bajados\%20marco/Ley1.doc (consultada el 11-12016).

43 Solo citando el caso de las dependencias judiciales, referiremos los casos del Palacio Nacional de Justicia, sede de la Corte Suprema de Justicia de la República, y del inmueble sede de la Corte Superior de Justicia de Lima, donde se han habilitado ambientes destinados al culto católico, locales en ambos casos denominados como: "Capilla Señor de la Justicia”. 
una determinada confesión; situaciones que no concuerdan con la laicidad del Estado que se propugna.

En conjunto, puede afirmarse que si bien la ley y su reglamento, parten del derecho fundamental de toda persona a la libertad de religión, se espera para nuestro país una mejor regulación que establezca con claridad su contenido y sus alcances, de manera que sea ejercido individual o colectivamente conforme al principio de laicidad el cual, como ha reconocido el Tribunal Constitucional peruano, tiene vigencia, al afirmar que en nuestro país el Estado es laico, como veremos a continuación.

\subsubsection{Jurisprudencia del Tribunal Constitucional}

Sobre la libertad religiosa, el Tribunal Constitucional peruano en el expediente $\mathrm{N}^{\mathrm{o}}$ 0895-2001-AA/TC, recurso extraordinario interpuesto por don Lucio Valentín Rosado Adanaque contra la sentencia de la Primera Sala Civil de la Corte Superior de Justicia de Lambayeque, de fecha 5 de julio de 2001, ha reconocido en el fundamento 3 que: "... la libertad de religión comporta el derecho fundamental de todo individuo de formar parte de una determinada confesión religiosa, de creer en el dogma y la doctrina propuesta por dicha confesión, de manifestar pública y privadamente las consecuentes convicciones religiosas y de practicar el culto". Agrega, a continuación, que "el derecho a la libertad religiosa tiene una vertiente negativa, que garantiza la libertad de cada persona para decidir en conciencia que no desea tomar parte en actos de la naturaleza antes descrita". Para el Tribunal Constitucional, en este fundamento, "la libertad de conciencia está vinculada a la libertad de ideas; mientras que la libertad de religión, a la libertad de creencias"; y reconoce que si bien ambos derechos gozan de pleno reconocimiento internacional, bien pueden ser "objeto de restricciones a favor de intereses superiores, como podrían ser la salvaguarda de la seguridad, la salud, la moralidad y el orden público"; por lo que no cree posible concebir un adecuado desarrollo de la libertad religiosa, "sin prestar las debidas garantías para el ejercicio de la libertad de conciencia".

Posteriormente, en la STC 0256-2003-HC, Caso Francia Sánchez, en el fundamento jurídico 16, el Tribunal determinó que "La libertad religiosa subsume a la libertad de culto, $y$ dentro de la libertad de culto, quedan garantizadas constitucionalmente todas aquellas ceremonias que la expresan, como las relativas al matrimonio y los ritos. Dentro de estos últimos, se encuentra la sepultura digna de los muertos por parte de sus familiares o seres queridos".

El Tribunal Constitucional continúa desarrollando la libertad de culto en el Exp. N. ${ }^{\circ}$ 3283-2003-AA/TC, fundamento 21, donde ha interpretado que: “La libertad religiosa no sólo se expresa positivamente en el derecho a creer, sino también en el derecho a practicar. Por ello, el derecho de libertad religiosa protege la libertad del acto de fe y la libertad de culto y la práctica religiosa. En ese contexto, la libertad de culto es entendida como la "atribución que tiene toda persona para ejecutar actos y 
participar en ceremonias representativas vinculadas con su creencia religiosa". (resaltado nuestro)

Luego, en la sentencia N. ${ }^{\circ}$ 3284-2003-AA/TC, en el fundamento jurídico 18 el Tribunal consideró que la libertad religiosa contiene cuatro atributos jurídicos, a saber: a) Reconocimiento de la facultad de profesión de la creencia religiosa que libremente elija una persona. b) Reconocimiento de la facultad de abstención de profesión de toda creencia y culto religioso. c) Reconocimiento de la facultad de poder cambiar de creencia religiosa. d) Reconocimiento de la facultad de declarar públicamente la vinculación con una creencia religiosa o de abstenerse de manifestar la pertenencia a alguna. (resaltado nuestro)

Respecto a los símbolos religiosos, el Tribunal Constitucional peruano dictó una controversial sentencia en el Exp. N $^{\circ}$ 06111-2009-PA/TC, del 7 de marzo de 2011, recurso de agravio constitucional interpuesto por don Jorge Manuel Linares Bustamante contra la resolución de la Primera Sala Especializada en lo Civil de la Corte Superior de Justicia de Lima Norte, de fecha 21 de julio de 2009, que, confirmando la apelada, declaró improcedente la demanda de amparo interpuesta por el recurrente contra el presidente de la Corte Suprema de Justicia de la República, en su condición de máximo representante del Poder Judicial, solicitando: a) que se ordene el retiro, en todas las salas judiciales y despachos de magistrados a nivel nacional, de símbolos de la religión católica como la Biblia o el crucifijo, y b) la exclusión, en toda diligencia o declaración ante el Poder Judicial, de la pregunta sobre la religión que profesa el procesado o declarante en general. Alega vulnerados sus derechos a la igualdad, a no ser discriminado por razón de religión, opinión o de otra índole.

El Tribunal, en la citada sentencia, conocida como "Sentencia de los Símbolos Religiosos en el espacio público", señaló en el fundamento 43 que: "... la presencia de símbolos religiosos como el crucifijo o la Biblia que se encuentran histórica y tradicionalmente presentes en un ámbito público, como en los despachos y tribunales del Poder Judicial, no afectan los derechos invocados por el recurrente ni el principio de laicidad del Estado, en tanto que la presencia de esos símbolos responde a una tradición históricamente arraigada en la sociedad, que se explica por ser la Iglesia católica un elemento importante en la formación histórica, cultural y moral del Perú, conforme lo reconoce la Constitución". El Tribunal prosigue abundando con argumentos de similar tesitura en los fundamentos 44 a 54, pero que se refugian finalmente en la tradición católica del pueblo peruano y en su papel en la formación histórica, cultural y moral del Perú. El fundamento 48 es revelador en tanto afirma que: "Ni la libertad religiosa ni la laicidad del Estado pueden entenderse afectadas cuando se respetan expresiones que, aunque en su origen religiosas, forman parte ya de las tradiciones sociales de un país".

Esta sentencia, consideramos, no solo contradice en varios aspectos el principio de laicidad del Estado, sino que además resulta objetable por el hecho de que ha 
fundado abrumadoramente su fallo en su propia jurisprudencia; quedando, por tanto, al margen de los avances que el derecho y la jurisprudencia comparadas de la época venían ya aportando, tal como se puede confrontar de la controversia resuelta por el Tribunal Europeo de Derechos Humanos, caso Lautsi ${ }^{44}$, caso al que hiciéramos referencia líneas arriba.

Por que si bien la implicación de símbolos religiosos en determinados actos públicos no supone una violación del principio de laicidad del Estado cuando dicha implicación, por encontrarse integrada en el tejido social de un determinado colectivo, genera una percepción actual de carácter polisémico, no estrictamente identificada con su contenido religioso, aún cuando para los fieles de una determinada religión lo siga teniendo, el argumento "cultural" no puede servir para justificar cualquier tipo de actuación o de implicación, pues no se podrá invocar ese carácter cultural o polisémico cuando de la actuación o implicación se deriven restricciones o ataques a derechos fundamentales o violaciones manifiestas del principio de laicidad del Estado $^{45}$.

En efecto, el Alto Tribunal peruano tampoco estimó en su fallo si la sola presencia de dichos símbolos en las instituciones públicas obedece o no a fines de promoción o adoctrinamiento religioso, lo cual contravendría la neutralidad del Estado frente a la Iglesia. El hecho de que al interior de las dependencias estatales se promuevan o fomenten las expresiones religiosas de una determinada confesión, en este caso de la Iglesia católica, se aparta objetivamente del modelo de separación Estado-Iglesia y del principio de laicidad, y cae dentro de un modelo de laicidad positiva el cual, como ha expresado Orozco ${ }^{46}$, más que valorar positivamente determinadas convicciones religiosas, exige por parte del Estado una actividad de promoción que claramente desconoce los alcances del principio de laicidad. En otras palabras, el principio de laicidad positiva convierte el Estado "laico" en confesional.

Y si bien el art. 50 de la Constitución establece en efecto un modelo de colaboración entre el Estado y las entidades religiosas -basado en dos premisas esenciales, la independencia y autonomía que deben servir de guía y camino a esas relaciones-, de ese modelo no se concluye la posibilidad de que las instituciones oficiales del Estado realicen actividades de fomento ni de la fe católica ni de ninguna otra, pues hacerlo violentaría esa independencia y autonomía; de ahí que lo más grave del caso que ha llegado al TC es verificar que este modelo de relaciones no se condice con la práctica

44 Cabe recordar que la decisión inicial del Tribunal de Estrasburgo, en el caso Lautsi, es del 3 de noviembre de 2009, la cual se mantuvo hasta el 18 de marzo del año 2011 cuando la Gran Sala del TEDH varió de criterio en una cuestionada sentencia.

45 AMÉRIGO Fernando y Daniel PELAYO. El uso de símbolos religiosos en el espacio público en el Estado laico español. Fundación Alternativas. Documento de Trabajo 179/2013, p. 65, en http://www.fundacionalternativas.org/public/storage/laboratorio_documentos_archivos/b6e3c3b94b3 4d60f979259c0bfbcbab8.pdf, (consultada el 21-11-2016).

46 OROZCOSOLANO, Víctor Eduardo. Op. cit., p. 162. 
real dentro de las instituciones públicas, que al confundir las cosas provocan gravosas consecuencias para terceros ${ }^{47}$.

De otro lado, el Tribunal Constitucional al denegar la pretensión de que el Estado retire los símbolos religiosos de los despachos y salas judiciales, argumenta en el fundamento 50 de su decisión lo siguiente: ".... Si el impacto de la sola presencia silenciosa de un objeto en un espacio público representase un trastorno de tal entidad, habría igualmente que prohibir la exposición de símbolos religiosos en las calles, como las cruces en la cima de los templos, ya que su presencia podría resultar emocionalmente perturbadora para los no creyentes"; de lo queda manifiestamente claro que el Tribunal Constitucional "confunde espacio público con espacio sujeto a la administración del Estado", como bien señala Mosquera ${ }^{48}$. La pretensión sometida al juicio del Tribunal en ningún supuesto pretende que se restringa la exposición de los símbolos religiosos católicos en el espacio público; máxime si como ya lo ha esclarecido la jurisprudencia del Tribunal Constitucional español en la STC 66/1995, FJ 3. "En una sociedad democrática, el espacio urbano no es solo un ámbito de circulación, sino también un espacio de participación" ${ }^{\prime \prime}$, y que por tanto no excluye la expresión religiosa.

Sí cabe destacar de dicha sentencia del Tribunal Constitucional peruano que al analizar en el fundamento 24 el artículo $50^{\circ}$ de la Constitución, reconoce acertadamente que nuestra carta fundacional consagra "el principio de laicidad del Estado, conforme al cual el Estado declara su "independencia y autonomía" respecto de la Iglesia católica o cualquier otra confesión religiosa. Se trata, por consiguiente, de un Estado típicamente laico o aconfesional, en el que si bien se proclama y garantiza la libertad religiosa, no se asume postura a favor de ninguna confesión en particular". Puntualiza aquí el Tribunal Constitucional que en el modelo peruano nuestro Estado se encuentra formalmente separado de toda confesión religiosa, y lo por tanto, no proclama como oficial religión alguna.

Otro aspecto rescatable de la sentencia en comento, es cuando el Colegiado al resolver la cuestión de la declaración individual de confesionalidad a través del juramento y del interrogatorio judicial, ha considerado fundada la demanda en este extremo, como se aprecia del fundamento 63: “... aunque se ha vuelto una práctica común (no normativizada) el que las autoridades judiciales interroguen a los justiciables respecto de la religión que profesan, tal interrogante resulta en abstracto impertinente además de invasiva en relación con la libertad religiosa (en este caso, a la facultad de mantener reserva sobre las convicciones religiosas), pues se inquiere por un dato que en nada contribuye al objetivo del proceso penal o en general a la administración de Justicia".

47 MOsQuerA, Susana. La libertad religiosa en el constitucionalismo peruano. Derecho, Instituto de Derechos Humanos, Repositorio institucional PIRHUA - Universidad de Piura, 2012, p. 22, en http:/ / pirhua.udep.edu.pe/handle/123456789/1708 (consultada el 22-12-15).

48 MOSQUERA, Susana. Símbolos religiosos en espacios bajo administración del Estado, Gaceta Constitucional, núm. 40, 2011, p. 120.

49 CONTRERAsMaZARÍo, José M. a y CELADOR ANGÓN, Óscar. Op., cit., p. 30. 
En el caso del Exp. N. ${ }^{\circ}$ 03372-2011-PA/TC, proceso de amparo contra el presidente del Consejo de Ministros, el presidente del Congreso de la República y otros, a fin de que se retire el Proyecto de Ley No 4022/2009-PE presentado por el Poder Ejecutivo con el cual se pretende declarar al Señor de los Milagros como Patrono del Perú, símbolo que el recurrente considera perteneciente a la Iglesia católica, por sentencia del 9 de marzo de 2013 el Tribunal fundamentó su fallo en la línea de los anteriores pronunciamientos: “... el derecho de libertad religiosa tiene una dimensión objetiva, contenida en el artículo $50^{\circ}$ de la Constitución, que determina, por un lado, el principio de laicidad del Estado y, de otro, el principio de colaboración entre el Estado y las confesiones religiosas" (fundamento 13).

Con lo expuesto, tenemos que al Tribunal Constitucional peruano le asiste un rol cardinal en la tarea de determinar los alcances de los derechos a la libertad de conciencia y libertad religiosa, tan íntimamente ligados, como admite el Tribunal, y en esa línea afinar sus procedimientos de ponderación, de manera que se brinde igual protección a la libertad de conciencia, sea religiosa o no religiosa, de las personas.

\section{Libertad de culto en las instituciones públicas}

\subsection{Libertad de culto}

La libertad culto, siguiendo a Huaco ${ }^{50}$, es uno de los dos derechos alusivos a la libertad de manifestar la religión, compuestos precisamente de los derechos de libertad de culto, de difusión e información religiosas, de enseñanza y educación religiosas, de reunión y asociación con fines religiosos, y los derechos de libertad de conciencia religiosa.

En efecto, es necesario delimitar correctamente el campo de la actividad de culto, es decir, todo lo que está relacionado directamente con el culto propio de cada una de las confesiones. El culto es la expresión y la actuación concreta en la que se manifiestan las diversas religiones. El culto, es el momento expresivo y manifestativo de lo que fundamentalmente es la religión ${ }^{51}$.

\subsection{Libertad de culto e instituciones públicas}

Las expresiones del derecho de libertad religiosa, en esa dimensión externa y colectiva que permite el culto en los espacios públicos o privados, como sería el caso de la exhibición de símbolos religiosos, han de diferenciarse de aquellas que tienen lugar o se pretende tengan lugar en espacios que están bajo la administración del Estado -en alguna de sus variadas estructuras y funciones-, pues son

50 HuACO PALOMINO, Marco. Derecho de la Religión. El principio y derecho de libertad religiosa en el ordenamiento jurídico peruano. Fondo Editorial de la Universidad Nacional Mayor de San Marcos, Lima, 2005, p. 28.

51 MARTíNEZSISTACH, Luis. Libertad religiosa y actividad de culto, en Memoria del IX Congreso Internacional de Derecho Canónico: "La libertad religiosa”. Instituto de Investigaciones Jurídicas. Universidad Autónoma de México, 1996, p. 306, en http:/ / biblio.juridicas.unam.mx/libros/1/175/18.pdf (consultada el 12-01-16) 
manifestaciones en las que el Estado debe ser muy escrupuloso a la hora de proteger el contenido del derecho de libertad religiosa, sobre todo si lo quiere hacer respetando los principios que vertebran el modelo de relaciones entre poder político y religioso ${ }^{52}$. Concretamente, la utilización de simbología religiosa en edificios públicos, como señala Orozco ${ }^{53}$, claramente es incompatible frente a los alcances del principio de laicidad, al menos en su mayor grado de desarrollo.

Ello nos conduce a reflexionar que, en efecto, la laicidad se configura, fundamentalmente, como un sistema de relación entre instituciones; asimismo, que la separación impide que exista una identificación entre los poderes públicos y la entidades religiosas, al tiempo que la neutralidad evita la confusión entre sus funciones y finalidades e impide que el Estado se adhiera a ninguna creencia religiosa ${ }^{54}$.

Esto es tan importante en el escenario latinoamericano como en el de otros países, máxime si la influencia política de la Iglesia mayoritaria en Latinoamérica es aún persistente, y como señala Blancarte, "en lugares como Perú o Centroamérica la confesionalidad del Estado únicamente se pluraliza pero no se laicizan las instituciones públicas" 55 . Sin embargo -en expresión del mismo autor- pese a tradiciones y presiones político-eclesiásticas, “... el Estado latinoamericano está siendo obligado a laicizarse. Sin embargo, al mismo tiempo, en muchos lugares esta tendencia parece estar luchando con la antigua lógica regalista y jurisdiccionalista, que usaba a la religión como parte de su política de cohesión y control social, dando paso a un esquema pluri-confesional de privilegios para las Iglesias más importantes o las más capaces de movilizar apoyo político. De esa manera, la laicización de las instituciones públicas que la democratización y la pluralidad religiosa suponen y exigen, se enfrenta a la opción de la pluri-confesionalidad, que está a su vez ligada a las tendencias clientelares y populistas de algunos regímenes. El resultado es una "tensión creciente entre dos modelos de sociedad; uno que perpetúa las antiguas tradiciones regalistas, jurisdiccionalistas e incluso laicistas y otro que aspira a una real democratización y des-sacralización del espacio público".

\subsubsection{Culto religioso en los actos oficiales del Estado}

El Estado no puede dictar lo que debe creer una persona ni adoptar medidas coercitivas para que manifieste sus creencias, ni obligarle a actuar de modo que se

52 MOsQUERA, Susana. Símbolos religiosos en espacios bajo administración del Estado, Gaceta Constitucional, núm. 40, 2011, p. 121.

53 OROZCOSOLANO, Víctor Eduardo. Op. cit,. p. 145.

54 AMÉRIGO Fernando y Daniel PELAYO.Op. cit., p. 12.

55 BLANCARTE, Roberto. América Latina. Entre pluri-confesionalidad y laicidad, Civitas, Porto Alegre, v. 11, n. 2, maio-ago. 2011, p. 204, en http://revistaseletronicas.pucrs.br/ojs/index.php/civitas/article/viewFile/9644/6738 (consultada el 291-2016). 
entienda que profesa determinadas creencias ${ }^{56}$; no obstante, se verifica en el escenario latinoamericano que las instituciones públicas imponen deberes de culto religioso a las personas que las integran, en tanto obligan bajo sanción disciplinaria a participar en manifestaciones de religiosidad en favor de una determinada confesión.

Tal es el caso de diversas instituciones públicas del Estado peruano, como el Poder Judicial cuyos actos oficiales de mayor relevancia -como son las ceremonias de Apertura del Año Judicial y por el "Día del Juez" - son de asistencia obligatoria, bajo sanción, para los señores jueces reunidos en Sala Plena, de conformidad con el art. $79^{\circ}$ del Texto Único Ordenado de la Ley Orgánica del Poder Judicial ${ }^{57}$, las mismas que incluyen dentro de su programación ceremonial paraliturgias religiosas oficiadas por un representante eclesiástico de la Iglesia católica; quien además ostenta cargo público a nombre del Poder Judicial ${ }^{58}$. La práctica de culto católico descrito es recurrente en las ceremonias públicas estatales, esto pese a que las leyes no prevén su existencia, o supediten la validez del acto oficial o administrativo a dicha presencia; en consecuencia, a las personas que laboran en las dependencias del Estado, trátese de autoridades, funcionarios o empleados públicos, les asiste la potestad de hacer prevalecer el derecho a la libertad religiosa y libertad de conciencia que la Constitución y las leyes garantizan.

En el caso específico de los jueces, dado el carácter imperativo y coercitivo de la citada norma orgánica, estos tienen el derecho de decidir en conciencia si desean o no tomar parte en las ceremonias oficiales del Poder Judicial, cuando consideren que los actos del culto religioso que forman parte de las ceremonias judiciales vulneran el derecho a la libertad de culto que les asiste; por lo que debe respetarse el principio de voluntariedad en la asistencia. Igualmente, los servidores públicos pueden negarse

56 OROZCOSOLANO, Víctor Eduardo. Op.cit., p. 57.

57 "Artículo 79. Órgano supremo: competencia, presidencia, integrantes y sesiones

La Sala Plena de la Corte Suprema es el órgano supremo de deliberación del Poder Judicial que, debidamente convocada, decide sobre la marcha institucional de dicho poder y sobre otros asuntos que no sean de competencia exclusiva de otros órganos, de acuerdo con lo establecido en la presente Ley. La preside el Presidente de la Corte Suprema y se integra por todos los jueces supremos titulares. El jefe de la Oficina de Control de la Magistratura no interviene en los casos que haya conocido con anterioridad en el ejercicio de sus funciones.

Se reúne en sesiones ordinarias y extraordinarias.

Las sesiones ordinarias se realizan, cuando menos, dos veces al año, siendo una de ellas para la apertura del año judicial. Las sesiones extraordinarias se realizan cuando las convoque el Presidente de la Corte Suprema o cuando lo solicite, por lo menos, un tercio de los miembros o cuando lo acuerde el Consejo Ejecutivo o cuando lo señale la ley.

El quórum es de la mitad más uno del número total de jueces supremos de la Corte Suprema. Los acuerdos se adoptan por mayoría simple. Las inasistencias injustificadas se sancionan con multa equivalente a un día de haber, debiendo publicarse la relación de los concurrentes e inasistentes en el Diario Oficial El Peruano." (el resaltado es nuestro)

58 En el caso de la Sala Plena de la Corte Suprema de Justicia de la República, oficiadas por el Capellán del Poder Judicial. 
por motivos religiosos a participar cuando se verifique la presencia y/o utilización de simbología o expresiones religiosas durante la realización de actos oficiales estatales de índole obligatorio, por cuanto tal hecho afecta el derecho de libertad religiosa, que garantiza la libertad de cada persona para decidir en conciencia si desea o no tomar parte en actos de contenido religioso.

De otro lado, en cuanto a la participación de los funcionarios públicos en manifestaciones religiosas a título personal o a título institucional, en el primero de los casos la asistencia o inasistencia del funcionario debe ser decidida libre y voluntariamente por el sujeto, ya que dicha elección forma parte del contenido de su derecho individual a la libertad de conciencia; pero en el supuesto de que la asistencia de los funcionarios tenga un carácter institucional, en la medida en la que el funcionario representa a los poderes públicos, cabe hablar de una vulneración del principio de laicidad del Estado, tanto en su faceta de separación entre el Estado y las confesiones religiosas como de neutralidad estatal 59 .

Sobre la presencia de símbolos religiosos en los actos de toma de posesión de cargos o funcionarios públicos -como líneas arriba ya se ha señalado- representa una vulneración del derecho a la libertad de conciencia y, supone la ruptura de las reglas del Estado democrático y, por lo tanto, del principio de laicidad estatal.

Por lo expuesto, la incompatibilidad entre los espacios destinados a la función pública estatal y las actividades de culto religioso -trátese de liturgia, adoctrinamiento o simbología de cualesquier confesión religiosa-, es manifiesta; tal como ha quedado evidenciada a la luz de la democratización de los Estados, del principio de laicidad, de los instrumentos y foros internacionales de protección del derecho fundamental a la libertad de conciencia y libertad religiosa, y de la doctrina y jurisprudencia más avanzada sobre la materia.

En suma, postulamos que en el caso concreto peruano -donde el Estado es laico conforme lo ha interpretado el Tribunal Constitucional-, el ordenamiento jurídico interno, las instituciones públicas, la justicia ordinaria y la justicia constitucional, deben ceñirse a los postulados del principio de laicidad, dentro del respeto a los derechos fundamentales de libertad de pensamiento, libertad de conciencia y libertad religiosa que ha consagrado el pensamiento jurídico nacional e internacional, como componente esencial de toda sociedad democrática y pluralista.

\section{Conclusiones}

a) La forma de organizar las relaciones que deben existir entre el Estado y la Iglesia, es uno de los aspectos más importantes del Derecho Constitucional y la base fundamental de una buena organización social. Ello es importante

59 CONTRERASMAZARÍo, José M.a y Celador Angón, Óscar. Op., cit., p. 35. 
porque el derecho a la libertad religiosa está necesariamente conectado con el sistema o modelo de relaciones Iglesias - Estado que rige en cada país.

b) La laicidad refiere a la separación entre el Estado y la Iglesia, y como tal es entendida como un régimen social de la convivencia cuyas instituciones políticas están legitimadas principalmente por la soberanía popular y no por elementos religiosos. Desde una concepción técnica jurídica, la laicidad es un principio constitucional que establece la separación entre el Estado y la Iglesia o las Iglesias que hasta ese momento hubieran servido como referentes normativos, así como el conjunto de mecanismos jurídicoinstitucionales que garantizan y desarrollan este principio.

c) La laicidad no afecta negativamente en ningún caso a la libertad de expresión o manifestación, individual o colectiva, de las convicciones y creencias, religiosas o no. Por el contrario, la laicidad es la única garantía eficaz del pluralismo, valor superior del ordenamiento y resultado del ejercicio de la libertad de expresión de las creencias, ideas u opiniones.

d) La libertad religiosa debe ser entendida como un derecho fundamental, tanto desde una perspectiva procesal, susceptible de tutela por medio de los recursos de amparo en los ordenamientos donde así se ha establecido, sino también desde una óptica material, en tanto se trata de un derecho que ha sido reconocido a cualquier ser humano por esa condición, inherente a la dignidad de cada uno de ellos.

e) La libertad religiosa tiene carácter subjetivo e individual, y se entiende como una cuestión privada, como resultado de la "libertad negativa" en materia de libertad religiosa. La libertad negativa significa que se protege también a quien tenga creencias areligiosas o antireligiosas (ateos, agnósticos, indiferentes, etcétera); $\mathrm{y}$, asimismo significa no estar sujeto a las prácticas religiosas de un grupo determinado, la libertad de no creer, de no ser adoctrinado u obligado a las prácticas religiosas de otros. Esto último atañe también a los creyentes de una religión respecto de las otras religiones, a los disidentes religiosos en relación a la ortodoxia de su propia religión y, en general, a cualquier creyente en relación a la propia religión, que se configura así como una "cuestión privada", un acto voluntario cuyas prácticas, ritos y manifestaciones no pueden ser exigidos a los individuos a través del Estado.

f) La libertad religiosa es la facultad o el derecho que tiene toda persona, sola o asociada, de vivir conforme o en desacuerdo con sus propias creencias o convicciones religiosas. La libertad de religión comprende tanto las acciones realizadas a partir de una valoración inicial positiva del fenómeno religioso, como las negativas: agnósticas o ateas. 
g) Las distinciones basadas en un mayor reconocimiento público, mayor protección y mayores posibilidades de acción a las prácticas de una de las religiones con las que el Estado tiene determinados acuerdos, comprometen el principio antidiscriminatorio en relación a las minorías religiosas, a las formas de creencia que no pueden estructurarse según el modelo de las religiones tradicionales, a la disidencia religiosa y a los no creyentes. El principio antidiscriminatorio cuestiona la acumulación de privilegio por parte de la mayoría o de los grupos religiosos dominantes, que es la otra cara de la desigualdad. El enfoque de la laicidad como relación EstadoIglesia(s)/confesiones, dificulta la capacidad del principio antidiscriminatorio para denunciar las estructuras de subordinación porque actúa como mecanismo de legitimación de la hegemonía de ciertas posiciones.

h) Estado laico es aquel que se encuentra fuera de toda influencia religiosa o de enseñanza religiosa. El Estado laico no se adhiere a ninguna religión, ni declara a una religión determinada como la oficial del Estado. No obstante, definir exactamente la actitud que el Estado asume frente al factor religioso es un problema complejo; problema que es común a todos los países occidentales en los que al parecer rige el principio de laicidad, porque aun cuando constitucionalmente se adopte el principio de laicidad como valor superior del ordenamiento jurídico de un Estado, dicho principio no es inmutable sino variable en función de los movimientos sociales, culturales y políticos, del momento. Dicho análisis debe tener en cuenta el marco concreto de laicidad y las dinámicas que pueden condicionar el funcionamiento de los mecanismos de separación.

i) El Estado no puede dictar lo que debe creer una persona ni adoptar medidas coercitivas para que manifieste sus creencias, ni obligarle a actuar de modo que se entienda que profesa determinadas creencias.

j) La jurisprudencia del Tribunal Europeo de Derechos Humanos ha venido evolucionando en su concepción sobre la vinculación de la libertad de conciencia, la libertad ideológica y la libertad religiosa, otorgando reconocimiento y protección al contenido esencial de dichos derechos; así como desarrollando el alcance de las posibles restricciones al ejercicio de la libertad religiosa, tomando en consideración el criterio del margen de apreciación de los Estados nacionales europeos, y el principio de laicidad del Estado. El criterio del margen de apreciación aboga por reconocer a las autoridades estatales un ámbito para apreciar la necesidad de ciertas medidas restrictivas; lo que comporta, respecto al derecho a la libertad religiosa, una aplicación particular del Convenio de Roma, según las circunstancias del caso. Los tribunales realizan, en tal cometido, un juicio de 
ponderación entre las normas del Convenio y las Constituciones, las circunstancias políticas, económicas y culturales de cada uno de los Estados.

k) Las Constituciones peruanas de 1979 y 1993 consagran el principio de laicidad del Estado, conforme al cual el Estado declara su "independencia y autonomía" respecto de la Iglesia católica o cualquier otra confesión religiosa. Se trata, por consiguiente, de un Estado típicamente laico o aconfesional, en el que si bien se proclama y garantiza la libertad religiosa, no se asume postura a favor de ninguna confesión en particular. En el modelo peruano nuestro Estado se encuentra formalmente separado de toda confesión religiosa, y lo por tanto, no proclama como oficial religión alguna.

1) La libertad culto es uno de los dos derechos alusivos a la libertad de manifestar la religión. El culto es la expresión y la actuación concreta en la que se manifiestan las diversas religiones. Es el momento expresivo y manifestativo de lo que fundamentalmente es la religión. Las expresiones del derecho de libertad religiosa, en esa dimensión externa y colectiva que permite el culto en los espacios públicos o privados, deben diferenciarse de aquellas que tienen lugar o se pretende tengan lugar en espacios que están bajo la administración del Estado -en alguna de sus variadas estructuras y funciones-, pues son manifestaciones en las que el Estado debe ser muy escrupuloso a la hora de proteger el contenido del derecho de libertad religiosa, sobre todo si lo quiere hacer respetando los principios que vertebran el modelo de relaciones entre poder político y religioso.

m) La utilización de simbología religiosa en edificios públicos, claramente es incompatible frente a los alcances del principio de laicidad, al menos en su mayor grado de desarrollo. La incompatibilidad entre los espacios destinados a la función pública estatal y las actividades de culto religioso trátese de liturgia, adoctrinamiento o simbología de cualesquier confesión religiosa-, es manifiesta; tal como ha quedado evidenciada a la luz de la democratización de los Estados, del principio de laicidad, de los instrumentos y foros internacionales de protección del derecho fundamental a la libertad de conciencia y libertad religiosa, y de la doctrina y jurisprudencia más avanzada sobre la materia.

n) Cuando los poderes públicos obligan a sus miembros a participar en actos o ceremonias oficiales de contenido religioso, están vulnerando el derecho de libertad religiosa y de culto de las personas que integran las instituciones públicas. El ejercicio de la libertad religiosa es inmune a toda coacción.

o) En el caso específico de los jueces, estos tienen el derecho de decidir en conciencia si desean o no tomar parte en las ceremonias oficiales del Poder 
Judicial, cuando consideren que los actos del culto religioso que forman parte de las ceremonias judiciales vulneran el derecho a la libertad de culto que les asiste; por lo que debe respetarse el principio de voluntariedad en la asistencia.

p) Respecto a la participación de los funcionarios públicos en manifestaciones religiosas a título personal o a título institucional, en el primero de los casos la asistencia o inasistencia del funcionario debe ser decidida libre y voluntariamente por el sujeto, ya que dicha elección forma parte del contenido de su derecho individual a la libertad de conciencia; pero, en el supuesto de que la asistencia de los funcionarios tenga un carácter institucional, en la medida en la que el funcionario representa a los poderes públicos, cabe hablar de una vulneración del principio de laicidad del Estado, tanto en su faceta de separación entre el Estado y las confesiones religiosas como de neutralidad estatal.

q) La presencia de símbolos religiosos en los actos de toma de posesión de cargos o funcionarios públicos representa una vulneración del derecho a la libertad de conciencia y, supone la ruptura de las reglas del Estado democrático y, por lo tanto, del principio de laicidad.

r) En el Estado peruano, que es laico conforme lo ha interpretado el Tribunal Constitucional, el ordenamiento jurídico interno, las instituciones públicas, la justicia ordinaria y la justicia constitucional, deben ceñirse a los postulados del principio de laicidad, dentro del respeto a los derechos fundamentales de libertad de pensamiento, libertad de conciencia y libertad religiosa que ha consagrado el pensamiento jurídico nacional e internacional, como componente esencial de toda sociedad democrática y pluralista.

\section{Bibliografía}

AMÉRIGO Fernando y Daniel PELAYO. El uso de símbolos religiosos en el espacio público en el Estado laico español. Fundación Alternativas. Documento de Trabajo 179/2013, p. pn http://www.fundacionalternativas.org/public/storage/laboratorio_documento s_archivos/b6e3c3b94b34d60f979259c0bfbcbab8.pdf

ARECES PIÑOL, $\mathrm{M}^{\mathrm{a}}$ Teresa. El principio de laicidad en las jurisprudencias española y francesa. Lleida, Ediciones de la Universidad de Lleida, España, 2003.

ARLETTAZ, Fernando. "La jurisprudencia del Tribunal Europeo de Derechos Humanos sobre la libertad religiosa: un análisis jurídico-político", en Revista Derechos y Libertades, Número 27, Época II, junio 2012, Instituto de Derechos Humanos Bartolomé de las Casas, España, en http://earchivo.uc3m.es/bitstream/handle/10016/19585/DyL-2012-27arlettaz.pdf?sequence $=1$ 
BLANCARTE, Roberto. América Latina. Entre pluri-confesionalidad y laicidad. Civitas, Porto Alegre, v. 11, n. 2, pp. 182-206, maio-ago. 2011, en http://revistaseletronicas.pucrs.br/ojs/index.php/civitas/article/viewFile/9644 16738

BOKSER LIWERANT, Judit. "Religión y espacio público en los tiempos de la globalización", en R. Blancarte (coord.): Los retos de la laicidad y la secularización en el mundo contemporáneo. El Colegio de México. Centro de Estudios Sociológicos, México D.F., 2008.

CARRETEROPASÍN, Angel Enrique. El laicismo. ¿Una religión metamorfoseada? Nómadas. Revista Crítica de Ciencias Sociales y Jurídicas, 15, (2007.1), pp. 239-248, en http://revistas.ucm.es/index.php/NOMA/article/view/NOMA0707120239A/ 26558

CONTRERAS MAZARío, José M.a y CELADOR ANGÓN, Óscar. Laicidad, manifestaciones religiosas e instituciones públicas, Fundación Alternativas. Documento de trabajo 124/2007,

en

http://www.fundacionalternativas.org/public/storage/laboratorio_documento s_archivos/xmlimport-5d6eWX.pdf

DE DIENHEIM BARRIGUETE, Cuauhtémoc Manuel. “El derecho a la libertad religiosa y la laicidad del Estado como presupuestos básicos del Estado Constitucional y Social de Derecho", en M. Vizcaíno, (coord.): Estado laico, democracia y derechos fundamentales. Facultad de Derechos y Ciencias Sociales UMSNH, México, 2010.

FUENTES MOLINAR, Olac: "El laicismo: seis tesis contrarias a la educación pública", en Bases Filosóficas, Legales y Organizativas del Sistema Educativo Mexicano. Secretaría de Educación Pública, México, 1997.

HuACO PALOMINO, Marco. Lo bueno, lo malo y lo feo de la ley de libertad religiosa: Texto integro de la ley y comentario, 2010, en http://www.marcohuaco.com/mh/bajados\%20marco/Ley1.doc

HuAco PAlomino, Marco. Derecho de la Religión. El principio y derecho de libertad religiosa en el ordenamiento jurídico peruano. Fondo Editorial de la Universidad Nacional Mayor de San Marcos, Lima, 2005.

HuRTADO HuaIlla, Ana Cecilia. Análisis jurisprudencial del derecho a la libertad religiosa. Centro de Estudios de Derecho Penal Económico y de la Empresa, 2015, en http://www.cedpe.com/blogs/Delitos_empresariales_y_derecho_procesal/?p= 22

LABACA ZABALA, María Lourdes. La libertad religiosa y el principio de laicidad en los centros educativos de Francia: a propósito de las manifestaciones religiosas ostensibles en las aulas, 2007 ,

en http://www2.congreso.gob.pe/sicr/cendocbib/con4_uibd.nsf/A3948EB41827E 67205257C7100745458/\$FILE/24-la-libertad-religiosa-y-principio-laicidad.pdf

LLAMAZARES FERNÁNDEZ, Dionisio. Libertad de conciencia y laicidad en las instituciones y servicios públicos. Editorial Dykinson Madrid, 2005. 
MARTÍNEZSISTACH, Luis. "Libertad religiosa y actividad de culto”, en Memoria del IX Congreso Internacional de Derecho Canónico: La libertad religiosa. Instituto de Investigaciones Jurídicas. Universidad Autónoma de México, 1996, en http://biblio.juridicas.unam.mx/libros/1/175/18.pdf

MORONDO TARAMUNDI, Dolores. El principio de laicidad y el principio antidiscriminatorio en la discusión sobre la libertad religiosa. Diritto e questioni pubbliche, n. 13/2013, Palermo, 2013,

en http://www.dirittoequestionipubbliche.org/page/2013_n13/stu_08Morondo.pdf

MOSQUERA, Susana. Símbolos religiosos en espacios bajo administración del Estado, Gaceta Constitucional, núm. 40, 2011.

MOSQuERA, Susana. La libertad religiosa en el constitucionalismo peruano, Derecho, Instituto de Derechos Humanos, Repositorio institucional PIRHUA Universidad de Piura, 2012, en http://pirhua.udep.edu.pe/handle/123456789/1708

Olmos ORTEGA, María Elena. El derecho a la libertad religiosa: un tema de nuestro tiempo, en http://www.ligaproderechoshumanos.org/articulos/maria-elena-olmosortega.pdf

OROZCO SOLANO, Víctor Eduardo. Laicidad y Libertad de Religión. Maestría en Justicia Constitucional, Universidad de Costa Rica, 2010, en http://sitios.poderjudicial.go.cr/salaconstitucional/articulos $\% 20 \mathrm{y} \% 20$ conferencias/Laicidad $\% 20 \mathrm{y} \%$ 20Libertad\%20de\%20Religion.pdf

PARDO PRIETO, Paulino C. "Secularización y Sistema Concordatorio Histórico Español de 1753 y 1851", en A. Pele, O. Celador Angón y H. Garrido Suárez (AAVV). La laicidad. Madrid, Editorial Dykinson, 2014.

PAREJA PAZSOLDÁN, José Derecho Constitucional peruano y la Constitución de 1979. Justo Valenzuela V., Lima, 1980.

PRECHT PIZARRO, Jorge Enrique. "La laicidad del Estado en cuatro Constituciones Latinoamericanas". Estudios constitucionales, noviembre, año/vol. 4, número 002, 2006.

REYES-TORRES, Amaury A. Una cuestión de apreciación: el margen de apreciación en la Corte Interamericana de los Derechos Humanos, 2015, en https://www.academia.edu/10416869/Una_cuesti\%C3\%B3n_de_apreciaci\%C3 \%B3n_El_margen_de_apreciaci\%C3\%B3n_en_la_Corte_Interamericana_de_los_ Derechos_Humanos

RUIZ BuRSÓN, Francisco Javier. "Novedades desde Estrasburgo sobre la objeción de conciencia". Revista General de Derecho Canónico y Derecho Eclesiástico del Estado, 31, 2013, www.unav.edu/matrimonioyfamilia/observatorio/uploads/30677_Ruiz_RGD CDEE2013_Novedades.pdf

RUIZ VIEYTEZ, Eduardo J. “La diversidad religiosa en el País Vasco: carencias y propuestas sobre su tratamiento jurídico e institucional", en E. Ruiz (coord.): $L a$ 
diversidad religiosa en el País Vasco. Nuevos retos sociales y culturales para las politicas públicas. Bilbao, Universidad de Deusto, 2011.

SANTANA, Alejandro. El Estado laico y la reforma constitucional. Consulta Anual 2009

Núcleo FTL República Dominicana - Iglesia, Poder y Misión en la República

Dominicana

Hoy, 2009,

en https:/ /ftldominicana.files.wordpress.com/2010/01/el-estado-laico-y-lareforma-constitucional-e28094-alejandro-santana.pdf

URRUTIA Abaigar, Víctor. "Laicismo y laicidad". FRONTERA, número 35, julioseptiembre 2005: Laicidad, laicismo y fe cristiana, en http://2001.atrio.org/PRIVADO/FRONTERA/35/35-VIctor.pdf 